OZAN YILMAZ*

\section{"Bir Münekkit Var Şarihten İçeri" Türk Şerh Edebiyatı'nda "Reddiye" Geleneği ve Sudîi-i Bosnevî Örneği}

\author{
The Tradition of "Refutation" in the Turkish \\ Commentary (Sharh) Literature and The \\ Example of Sudî-i Bosnevî There is a Critic in \\ The Commentator
}

Ö Z E T

Türk Şerh Edebiyatı, İran-Arap klasikleri ile tasavoufî muhteval manzumelerin şerhedildiği metinleri kapsayan genel bir başlıktır. Her biri ayrı öneme sahip şerhler, barındırdıkları kıymetli bilgilerin yanısıra edebî tartışmalara ev sahipliği yapmalarıyla da dikkate değer eserlerdir. Nitekim 16. yüzyıldan itibaren bazı şerh metinlerinde, şarihlerin birbirlerinin yaptıkları yorumları tenkit ettiğ $i$, yeri geldikçe itirazlarda bulunduğu görülmektedir. "Reddiye" adı verilen bu gelenek, aynı zamanda şarihler arası bir rekabetin metinle takip edilebilen yönüdür. Bu geleneğin hatırı sayılır temsilcilerinden biri de 16. yüzyıl şarihlerinden Sudî-i Bosnevî̀dir. Sudî, Fars edebiyatının klasik eserlerinden Gülistân, Bostân ve Divan-ı Hafiz'ı şerhetmekle kalmamış, aynı eserleri şerheden diğer şarihlerden bazılarının yorumların eleştirip, beğenmediği kısımları reddetmiştir. Bu makalede, öncelikle Türk Şerh Edebiyatı'nda reddiye geleneği hakkında bilgi verilecek, ardından Sudînnin reddiye anlayışı, eserlerinden seçilmiş örneklerle muhteva ve üslup açısindan ortaya konacaktır.

A N A H T A R K E L İ M E L E R

Şerh, Reddiye, Sudî Bosnevî, Şerh-i Gülistân, Şerh-i Bostân, Şerh-i Divan-ı Hafiz.
A B S T R A C T

Turkish Commentary Literature, as an umbrella term, encompasses the commentary texts in which PersianArabic classics and sufic poetries are evaluated. Commentaries are invaluable resources not only because they provide invaluable insights and information about the original work, but they also provoke the emergence of literary discussions. Since $16^{\text {th }}$ century, these discussions have led some commentators to criticize and refute other commentaries on a specific work. This literary tradition, which is called "refutation/reddiye", enables the tracking of the competetive behaviour amongst various commentators by means of the "text". One of the most important representatives of this tradition is Sudî- $i$ Bosnevî, a $16^{\text {th }}$ century commentator. Sudî, not only commented Gülistân, Bostân and Divan-ı Hafiz but also criticized and refutated other commentators who commented the same works. The current article first discusses the tradition of refutation in the Turkish Commentary Literature and then describes Sudîs understanding of refutation in terms of content and style by providing respective samples from his work.

\section{K E Y W O R D S}

Commentary, Refutation, Sudî̀-i Bosnevî, Commentary of Gülistân, Commentary of Bostân, Commentary of Divan-ı Hafiz.

"Yrd. Doç. Dr., Sakarya Üniversitesi, Fen-Edebiyat Fakültesi, Türk Dili ve Edebiyatı Bölümü, Sakarya (oyilmaz@sakarya.edu.tr). 
Türk Şerh Edebiyatı, İran ve Arap klasiklerinin yanısıra, tasavvufî muhtevalı Türkçe manzumeleri açıklayıp yorumlamaya dayalı şerh metinlerini kapsayan geniş bir sahadır. ${ }^{1}$ Mana ve muhtevasını herkesin kolay anlayamayacağı bazı eserler, 16. yüzyıldan 20. yüzyıla değin "metin şerhi" alanında kalem oynatan onlarca şarih tarafından ele alınarak şerhedilmiştir. Şerh metinleri, değerlendirilen eserlerin muhteva-biçim özelliklerinin yanısıra hemen her kesimi ilgilendirecek kültürel malzemeler içermektedir. Şerhlerin, dikkat çekici bir diğer özelliği de edebî tartışmalara ev sahipliği yapmalarıdır. Zira, klasik eserlere yazılmış bazı şerh metinlerinde açık bir "tenkit anlayışı" hâkimdir. ${ }^{2}$ Bu anlayışa sahip şarihler, diğer şarihlerin görüşlerine dair yorumda bulunmuş, bu yorumlar sırasında eksik yahut kusurlu gördükleri birtakım ifadeleri çürütmeye çalışmış, bu amaç doğrultusunda konuyla bağlantılı tenkit ifadeleri kullanmıştır. Bu ifadelere, şerh metinlerinin der-kenarında bazen şarih bazen de müstensihlerce yazılmış "redd-i..." şeklinde başlayan ibarelerden hareketle "reddiye" adını vermek mümkündür. Eldeki örneklere bakılırsa bir gelenek sayılabilecek bu yöntem, bir tür akademik disiplin gözeten bazı şarihlerin, "bir metni en iyi şekilde şerhetmek" iddiasılla metinler arası bir rekabete giriştiğini göstermektedir. ${ }^{3}$

1 'Şerh' ve 'Şerh Edebiyatı' kavramları ve Türk Şerh Edebiyatı'nın Türkçe örnekleri hakkında bkz. (Ceylan 2000: 19-33), (Ceylan 2010: 38, 565-568), (Yilmaz 2007: 271304). Ayrıca şerh ve haşiye geleneği hakkında bkz. (Kara 2011: 19-66).

${ }^{2}$ Klasik Türk Edebiyatı'nda tenkit anlayışı, sadece şerh sahasıyla sınırlı değildir. Klasik Türk şiiri metinlerinde de tenkit örneklerine rastlanır. Cafer Çelebi (ö. 1515), Hevesnâme adlı eserinde Şeyhî (ö. 1431?) ve Ahmed Paşa'yı (ö. 1497) tenkit ederken (Sungur 2001: 71-77), 16. yüzyıla ait tezkire metinlerinde şairlerin birbirlerine yönelttikleri eleştirilerden bahsedilmektedir (Tolasa 2002). Ayrıca, şairin şairi tenkit etmesini, mesnevî ve divanlardan seçilmiş örnekler üzerinde görüp bu tenkitlerin nedenleri hakkında bilgi edinmek için bkz. (Coşkun 2007).

${ }^{3}$ Hemen belirtmek gerekir ki reddiye/polemik, esasen "bir inanç veya düşünceye karşı çıkıp delil ve dayanaklarını çürütmek amacıyla kaleme alınan eserlerin genel adı (Sinanoğlu 2007: 34, 516)"dır. Nitekim bu anlayış, epey yaygınlaşarak bir süre sonra gelenek hâline gelmiştir (Batuk 2007: 39-68). Bizim bu makalede kullandığ1mız "reddiye" terimi, şerh sahasında şarihlerin birbirlerini eleştirmek amacıyla kaleme aldıkları tenkit ifadelerini belirtmek içindir; hasılı, değerlendirmeye aldığımız bu tür reddiyelerin dinî bir hüviyeti yoktur. 
Hemen her biri medrese tahsiline sahip ${ }^{4}$ donanımlı şarihler tarafından yazılan reddiyelerin, 16. yüzyıldan 20. yüzyıla uzanan birçok örneği vardır. Reddiye örneklerinin en yoğun görüldüğü dönem 16. yüzyıldır. Bu yüzyılda, özellikle Gülistân $n^{5}$, Bostân $n^{6}$ ve Divan-ı Hafiz ${ }^{7}$ gibi klasik eserleri şerheden bazı şarihler, eksik yahut kusurlu buldukları yorumları tenkit ederken reddiyeler ileri sürer. Bu şarihlerden Kefevî Hüseyin Efendi $^{8}$ (ö. 1601), 1601 yılında Mekke kadılığ1 yaparken tamamladığ1 Bostân-efrûz-ı Cinân der-Şerh-i Gülistân adlı eserinde Sudî, Sürurî, Şem'î, İbn Seyyid Ali ve Lamiî́yi çeşitli yönlerden tenkit eder. Bazen de adı geçen şarihlerden alıntı yapmak suretiyle ilmî bir anlayış gözetir. Mesela aşağıdaki örnekte', İbn Seyyid Ali ve Lamiî́nin şerhlerine gönderme

${ }^{4}$ Osmanlı'da medrese öğrencilerine öğretilen "Âdâb" ve "Mantık" ilimleri, tartışma becerisi kazandırmasının yanısıra, fikir çürütme, karşı görüş üretme ve muhalefet gibi hususların öğreniminde önemli bir işleve sahiptir. Öğrencilere, bilhassa fıkhî problemlerde "engelleme (men'), nakz, muâraza" gibi üç ayrı yöntem öğretilip uygulamalar yaptırılmıştır (Adanalı 2001: 41-42). Şerh metinlerindeki "reddiye"lerde rastladığımız "habt (bir bahis veya münazarada karşısındakinin hatasını ispat edip onu susturma), nazar var (münazara edilmeli), tadlîl (dalalete düşürme), techîl (bir kimsenin cahilliğini ortaya çıkarmak), taarruz eyleme (saldırma), muteriz-muteraz (itiraz eden-itiraz edilen), nâkıs (eksik)" gibi kullanımların biraz da Âdâb ve Mantık ilimlerine dair konuların etkisiyle metinlerde yer aldığını, şarihlerin medrese eğitimi sırasında edindikleri bu bilgileri yeri geldikçe kullandıklarını düşünüyoruz.

5 Türk edebiyatında Gülistân tercüme ve şerhleri için bkz. (Kartal 2001a: 99-125) (Yilmaz 2012: XXXV-XLIII).

${ }^{6}$ Türk edebiyatında Bostân tercüme ve şerhleri için bkz. (Kartal 2001: 99-120).

${ }^{7}$ Türk edebiyatında Divan-ı Hafız şerhleri için bkz. (Yılmaz 2007: 278-279).

${ }^{8}$ Kefevî Hüseyin Efendi (ö. 1010/1601): Osmanlı kadısı, müderris ve edip. Kırım'ın liman şehri Kefe'de doğup büyüdüğünden "Kefevî" nisbesiyle anılmıştır. Kefe'de emlâk sahibi bir tüccar iken ilim tahsili için İstanbul'a gitmiş, Kanuni devrinin sonlarında İstanbul'daki medreselerde dinî ve aklî ilimler okutmuştur. Ömrünün sonlarına doğru Sahn-1 Semân müderrisliği ile Kudüs ve Mekke kadılığı görevlerinde bulunmuş, 1601'de Mekke'de vefat etmiştir (Akpınar 2002: 186). Üç dilde şiir söyleme kabiliyetine sahip Kefevî Hüseyin Efendi, şarih kimliğini Gülistân için kaleme aldığı Bostân-efrûz-ı Cinân der-Şerh-i Gülistân adlı eserinde gösterir.

${ }^{9}$ Bostân-efrûz-ı Cinân der-Şerh-i Gülistân'dan seçtiğimiz örnekleri, eserin Süleymaniye Kütüphanesi Hamidiye bölümü 1159 numaralı nüshasından faydalanarak çalışmamıza dahil ettik. 
yapıp, isim vermeden "ba'z-1 ehâlî-i Rûm" diyerek Sudî'nin yorumunu (Şerh-i Gülistân, 22b) şerhine katmış, Celalî takvimdeki Ürd-i Behişt ayıyla ilgili bilgi verdikten sonra Sürurî'nin yorumunu reddetmiştir:

Tārīh-i Celālīde mu'teber olan Ürd-i behişt elbette gül zamānıdur. Tevārīh-i muhtelifenüñ tafṣîli Seyyid 'Alizāde ve Lāmi'ī şerḥlerinde mežkūrdur. Huafī olmaya ki ba'ż-1 şurrāḥuñ taḳrīrleri üzre Ürd-i behişt lafẓı kesr-i tā ile māha mużāf olup ve tārīhn-i Celālī ḳamerī olmaḳ fehm olınur. Ammā faḳīr ba'ż-1 ehālī-i Rūm haț̣tı ile gördüm böyle taḥ̣ịk itmiş ki ürd-i behiştmāh 'ibāreti tānuñ sükūnıla terkīb olup mecmū's ism-i şehr ola. Ve sā'ir esāmī-i şühūr dahı böyle olup meselā Ferverdīnmāh dirler nūnuñ sükūnıla. İntehā. Kelām-1 ba'ż̇-1 şurrāḥ bu taḥḳịe taḳlīd idüp iżāfetdür diyenleri redd itmiș ve tārīhn-i Celālī ḳamerīdür diyenleri daḩı taḍlīl ü techīl idüp tārīhn-i ḳamerī 'Araba mahșūṣdur, mā'adāsı cümlesi şemsī-i ḥaḳị̣̂īür dimiş. Ba'ż-1 şurrāḥ bahāruñ evveli māh-1 celālī diyü terceme itmişdür. Ma'nā-yı maḳșūda bu 'ibāretüñ delāleti yoḳdur. Kemā lā-yahfī (Redd-i Sürūrī), (Bostân-efrûz-ı Cinân der-Şerh-i Gülistân, 29b).

Eserini Sudî'nin şerhinden sonra kaleme alan Kefevî, Sudî'yi eleştirdiği aşağıdaki örneklerin ilkinde, şarihi "bâ-vücûd-1 în ma'nî" yapısına yanliş anlam vermesi sebebiyle, ikincisinde "tâ "harfinin harf-i tenbîh değil, harf-i ta'lîl olması gerektiği üzerine, üçüncüsünde de sıfat tamlamasına belirtisiz isim tamlaması dediği için reddeder:

Bu maḥalde bā-vücūd-1 īn ma'nī 'ibāretine "bunuñ birle" diyü ma'nā viren şāriḥ gāāibā ma'nādan ḩaber-dār olmamış (Redd-i Sūdī), (Bostân-efrûz-ı Cinân der-Şerh-i Gülistân, 133a).

Tā bidāñ̄ ki: Tā, hattā ma'nāsınadur, ta'līl içündür. Hattā ta'allüm ma'nāsı maḳṣūddur. Tā, ḥarf-i tenbīhdür diyenler bu ma'nīden gaāfildür (Redd-i Sūdī), (Bostân-efrûz-ı Cinân der-Şerh-i Gülistân, 137b).

Şāhed-i Belh̄ī terkībi tavṣîīìür. İżāfet-i beyāniyye zu'm iden galaṭ itmişdür (Redd-i Sūdī), (Bostân-efrûz-ı Cinân der-Şerh-i Gülistân, 138a). 
Diğer 5 şarihin yazdığı Gülistân şerhlerini gören, bunun bir getirisi olarak oldukça kapsamlı ve gözden geçirilmiş bir şerh kaleme alan Kefevî́nin onlara yazdığı reddiyelerden bazıları şöyledir:

Zād lafẓı lāzım ve müte'addī olup ba'ż-1 şurrāḥ lāzım oldugì taḳdīrce zā lafẓı zāyed olur dimişdür, zāyid söylemișdür (Redd-i Lāmicī), (Bostân-efrûz-ı Cinân der-Şerh-i Gülistân, 34b).

Ba'ż-1 şurrāḥ şeb-pere 'ibāretinüñ așlı perendedür dimişler. Ba ż̇lar redd idüp şeb-pere aṣl-1 vaż üzre lügatdür dimişler. Hak budur ki șeb-perendeden me'hūz olmaġa māni' yokdur (Redd-i Seyyid Ali), (Bostân-efrûz-ı Cinân der-Şerh-i Gülistân, $\left.48^{a}\right)$.

Ba'ż-1 şurrāḥ rāst ḩ'āhī 'ibāretin şarț-1 maḥzūfa cevāb țutup dimiş ki: Eger sen "āfitāb-1 siyāh u bī-fürūg olmaḳdan ise hezār buncılayın göz kör olmak yegdür" dirseñ ve böyle olduginn isterseñ șahịḥ söylersin ve rāst dilersin. Ba'ż-1 şurrāḥ dahı bu ma'nāyı iḩtiyār idüp velākin şarṭ-1 maḥzūūa i'tibār itmek lāzım degüldür ol tekellüfi irtikāb itmedin daḩı bu ma'nā dūst u çespān olur dimiş. Ya'nī āfitāb siyāh olmaḳdan biñ böyle göz a'mā olmak yegdür didügüñ hạḳ sözdür dimek ola. Hafī degüldür ki bu makūle tevcīhāt-1 baīde ve tekellüfāt-1 gayr-1 sedīdeyi ihtiyār u irtikāb rāh-1 șavābdan șad merhale dūrdur (Redd-i Sürūrī), (Bostân-efrûz-ı Cinân der-Şerh-i Gülistân, 48a).

(Açıkçası, böyle uzak anlamları ve sağlam olmayan uzun uzadıya yorumları seçip göze almak, doğru yoldan yüz kere uzaktır)

Gīr ü dār emrlerine mahal olmak i'tibārı ile cenge gīrūdār dirler. Dārugīr de dirler keșret-i isti'māl ile. İkisi bir kelime mesāâbesinde olup urmak țutmak mánāsında da müsta'meldür. Ba'ż-1 şurrāḥ bu ma'nādan gāfil olup dimiş ki "ya'nī țumțurāk u țanțana ve șavul yort". Bunuñ isti'māli budur, gaflet olunmaya (Redd-i Şem '̄i), (Bostân-efrûz-ı Cinân der-Şerh-i Gülistân, 72a).

Ve żamīr-i şīn ān lafz̧ıyla müşārun ileyh olan maḥbūba rāci'dür. Hoş püsere rāci'dür diyen sehv itmiş. Kiye rāci'dür diyen galat idüp $k i$ laf̣̣ı bu mahalde rābıța oldugin bilmemiș (Redd-i Sürūrī ve Seyyid 'Alizāde), (Bostân-efrûz-ı Cinân derŞerh-i Gülistân, 133b). 
Sudî'nin Gülistân Şerhi'nde geçen aşağıdaki örneklere göre Sürurî, İbn Seyyid Ali, Şem'î ve Kâfî reddiye ifadelerine yer vermiş, bilhassa Lamiî, diğerlerine göre Gülistân'ı ilk şerheden olduğu için diğer şarihler tarafından sürekli eleştirilmiştir. Bu eleştirileri değerlendiren Sudî, "mu'teriz (itiraz eden) - mu'teraz (itiraza uğrayan), bî-vech taarruz eylemiş (sebepsiz yere saldırmış), zâid söylemiş (gereksiz söylemiş)" gibi ifadeler kullanarak bazı değerlendirmelerde bulunmuştur. Şarih, bazen haklı gördüğü herhangi bir şarihi savunmuş, bazen de kimi şarihleri diğer şarihlere yönelttikleri reddiyeler yüzünden reddetmiştir:

Lāmi'ī Çelebi "ṣallū', fi'l-i māżīi cem’-i müzַekker-i gā'ibdür" dimiş ammā ma'nāsını "șalavāt getürüñ" dimiş. Pes bu hațā ya kendinüñ sehv-i ḳalemindendür veyā nāsıh̆-1 evvelüñ. Ve illā Lāmi'ī ol maḳāmda degüldür ki andan böyle hațā kașd-ıla șādır ola. Pes bu hatāyı zāt-1 Lāmi'īye isbāt u isnād eylemek mertebesini teșhīs eylememekden gelür (Redd-i Şemī ve Kāfī), (Şerh-i Gülistân, 7a).

(Bu yanlıșı Lamiî̀nin kendisine maleylemek, Lamiî́nin derecesini ayırt edememekten ileri gelir)

Nevānuñ lügatlerde mezkūr olan ma'nālarını bunda cem' idüp maḥalle münāsib ü mülāyimini ta'yīn eylemeyüp nevāyı zād ile tefsīr idene ítirāż eyleyen kendi mu'teraż olmışdur (Redd-i İbn Seyyid 'Ali), (Şerh-i Gülistân, 126a).

Rāstdan murād șịhhatdür ya'nī ṣaḥị̣ esbāb. Ya'nī tecrübe-i șahịḥ ile mücerreb esbāb-1 mu'ālecedür. "Esbāb-1 ma'āş" diyen beytüñ fehvāsına zererrece vāṣıl olmamış. Ġarābet bundadur ki "tecrübe-i șahīḥ ile mücerreb olan mu'ālece nef' eylemez" diyenüñ kelāmina i'tirāż eylemiş ki maḳāma münāsib degül diyü ammā kendi mu'teraż olduggından haber-dār degül. 'Afa'llāhü 'anhü (Redd-i Sürūrī), (Şerh-i Gülistân, 127a).

Şārihüuñ birisi mıșrā'-1 șānīnüñ ma'nāsını "güler yüzinden ferah ve müsterīh olasın" dimiş ve birisi "müsterīh" 'ibāretini terk idüp ta'așṣub țarīḳyla yalñı "ferāḥ" 'ibāretini isnād idüp i'tirāż eylemiş. Līkin bu huṣūṣda kendi mu'terażdur. Ve ma'nāsını "ki anuñ yüzinden ol ḥālde āsūde vü mesrūr dönesin" diyen ma'nāyı yabana döndürmiş (Redd-i Sürūrī ve Şem̄î), (Şerh-i Gülistân, 129b). 
"Dü Dervīş-i Horasan̄̄" ḥikāyesinde nevānuñ ma'nāsını beyān eylemeyüp bunda Șıhāḥ-1 Fürsden ni'metle tefsīr idene ta'arruż eyleyen bì-vech ta'arruż eylemiș (Redd-i Sürūrī), (Şerhi Gülistân, 129).

"Hazef, hā vü zā-yı mu'ceme ile saḳsı pāresi" diyene i'tirāż eyleyen zā'id eylemiş (Redd-i Sürūrī), (Şerh-i Gülistân, 133a).

Hānmān, ev ve barḳ ma'nāsınadur ammā Ni'metullāh "māl ve mülk ve țavar" dimiş. Pes, "māl ve rızḳ" diyene daḩl iden zā'id itdi (Redd-i Sürūrī), (Şerh-i Gülistân, 190a).

17. ve 18. yüzyıl şerh örneklerinden hareketle, reddiye geleneğinin devam ettiğini söyleyebiliriz. Sebk-i Hindî şerhlerinin yaygın olduğu bu döneme ait şerhlerde, isim vermek suretiyle yapılan reddiye örneklerine rastlanır. ${ }^{10} \mathrm{Bu}$ dönem şarihlerinin, şerhetmeye layık gördükleri şair Urfî-i Şirazî̀dir (ö. 1591). Urfî̀nin kasideleriyle uğraşıp onun 'müşkil' beyitlerini şerhetmek şarihler arasında büyük bir marifet sayılmış, bu konuda usta şarihler, edebî mahfillerde "Urfî-dân (Urfî̀yi bilen)" lakabıyla anılmaya başlamıştır. Neşatî (ö. 1674) de, bu Urfî-dân şarihler arasındadır. Neşatî, yeri geldikçe diğer şarihler hakkında görüş beyan etmiş, reddiye ifadeleri kaleme almıştır. Mesela aşağıdaki örnekte, diğer Urfî şarihlerinden İsmetî́nin (ö. 1665) yorumunu beğenmiş, bir başka şarih olan Ahund-1 Kazvinî’nin görüşünü reddetmiştir:

Bu ḳıṭ̂a-i müşkilteri 'İṣmetī Efendi merhūm bu vechle şerh eyleyüp dir ki: "Gevher-i girān-māye-i zāât-1 risālet-penāhuña

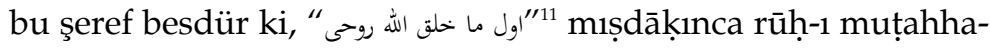
rañuñ hilḳatine irāde-i ezeliyye ta'alluḳından maḳ̣ad-1 aṣlī, raḥmet-i 'ālemiyān 'ālem-i vücūdı teşrīfüñ irāde-i ḳadīme-i İlāhiyye rūḥ-ı mükerremünüün halk u īcādın ta'alluk itmekle iḳlīm-i ḳıdeminden güzāâr itdigüñ vaḳitde sa'ādetle nüzūl ve bi'śetüñ hengāmina gelince ābā vü ümmehātdan vesā'il-i vücūd-1 bī-nazīiüũ olmağ-içün makșūud-ı aṣlī olmayan niçe efrād halḳına da irāde ta'alluḳ itmişdür" dimek olur. Ammā Āhund-1

${ }^{10}$ Urfî̀nin kasidelerine yapılan Türkçe şerh örnekleri için bkz. (Yılmaz 2004). Urfîdân şarihler arasında, Urfî́nin bir beytinde geçen "abes" kelimesi sebebiyle çıkan tartışma ve şarihlerin bu konu hakkındaki görüşleri için bkz. (Çaldak 2005: 71-84).

11 "Allah önce benim ruhumu yarattı". Hadîs-i şerîften iktibastır. 
Kazvīnī merhūm bu vechle ma'nā virüp dir ki: "Abes, lügatde lu'b ma'nāsınadur ve lu'b elbette eșnā-yı sürūrda olur. Bes lu'bdan murād sürūr olup be-sürūr bāz terāşīde ḳalem-rā dimek olur. Bu ma'nā çendān yerinde degildür. Zīrā sürūr daḥı bir te'vīle muhtāc olur (Şerh-i Ba'z-ı Müsşkilât-ı Urfî, 202a-202b).

18. yüzyıl şarihlerinden Murtaza Trabzonî1 ${ }^{12}$ ise, Urfî́nin kasidelerine yazdığı şerh örneklerinde bazen diğer şarihlerin verdiği manaları beğenmediğini dile getirerek reddiye geleneğini devam ettirir. Şarih, Neşatî ve Nazîrî́nin (ö. 1622) Urfî kasideleri üzerindeki birtakım yorumlarını gereksiz ve manasız bulup, bu tip şarihler yüzünden Urfî́nin şanına gölge düştüğünü söyleyecek kadar iddialıdır:

Beyt-i mežkūra zurefā-yı zamāne haylī tekellüfe düşüp derdmend 'Urfīyi kimi tekfīr ü kimi techīl itmişler. Bī-çāre 'Urfīnüñ fażl u kemālin bilmedüklerindendür (Şerh-i Kasâ'id-i Urfî, 13a).

Bu beyt eşkel-i müşkilātından 'add olınmağla Neşāțī ve Nazīiri merhūum 'aẓim tekellüflere düşüp șifā-yı șadr virür bir ma'nāya muvaffak olamaduklarıdur (Şerh-i Kasấid-i Urfî, 13').

'Urfīnüñ kașāyidi içinde olan müşkil ebyātuñ ba'żların zurefā-yı selefden Neşāțī merḥūm ile Etmekcizāde ve Naẓīī merḥūm ile Rodosīzāde bi-ḥasebi'ṭtṭạ̄a şerḥ idüp yārān-1 İstānbūl mecmū'alarında ceste ceste yazılmış bulınmag̉la faḳīr dahı ba'żların gördüm. Rodosīzāde merhūm ile Nazị̂̄ī merhūmuñ țab'ları müstaḳim ve kendileri ehl-i 'ilm olduḳlarıy-çün şerh eyledükleri de geregi gibi nefsü'l-emre muțābık olup 'Urfīnüñ murādın beyān itmişlerdür. Anlardan mā'adā ne kadar șārih görildi ise fikrleri sakīm olmag̉la 'Urfīnüñ murādından șad merhale dūr-ā-dūr vāki olmıșdur. Bu beyt dahı anlaruñ cümlesinüñ müşkil ḳıyās idüp şerḥinde dāğ-berdil olduḳları beytdür (Şerh-i Kasâ'id-i Urfî, 42a-42b).

Yine 18. yüzyılda Sudî, bir kelimeye verdiği anlam sebebiyle eleştiriye uğrar. Bu defa kendisini tenkit eden yine Türk Şerh Edebiyatı'nın kıymetli isimlerinden İsmail Hakkı Bursevî’dir (ö. 1725). Bursevî, Sudî’nin

\footnotetext{
${ }^{12}$ Murtaza Trabzonî ve şerhleri hakkında bkz. (Yılmaz 2010: 139-158).
} 
Hafız Divanı Şerhi'nde geçen bir beyitteki "zünnâr" kelimesine verdiği anlamı beğenmeyip, bu durumun lügate muhalif olduğunu şöyle anlatır:

"Sudînin Divan-ı Hafiz Şerhi'nde gelir ki, zünnâr Nasârânın alâmât-ı küfrden bir alâmetidir ki, kuşaklarma bend edip kuşakdan aşă̆a sarkıdırlar. Hâsılı görmeye mevkûfdur, intehâ. Pes Sudînin yazdı̆̆ı, lügate muhâlifdir. Velâkin câizdir ki, zamân-ı evvelde nefs-i kemerde, sonra kemerlerine bend ile iktifâ ettikleri alâmet ola" ${ }^{13}$ (Bursevî 2004: 638).

20. yüzyılda, Ahmed Avni Konuk'un (ö. 1938) Sofyalı Bâlî Efendi'yi reddettiği görülür. İbnü'l-Arabî'nin Fusûsu'l-Hikem ${ }^{14}$ adlı meşhur eserini şerheden Konuk, "Firavun'un İmanı" bahsinde hem kendisinden önceki şerhleri özetlemiş hem de kendi görüşlerini dile getirmiştir. Bu konuda diğer şarihlerden Abdürrezzak Kâşânî, Davud-ı Kayserî, Yakup Han ve Abdullah Bosnevî̀ye muhalif görüşler getiren Sofyavî Bâlî Abdullah Efendi ${ }^{15}$ 'nin fikirlerini maddeler hâlinde özetleyip uzun uzadıya cevaplamaktan, netice itibarıyla reddetmekten geri durmamıştır (Kara 2011: 55).

Reddiyelerdeki üslup incelendiğinde, en iyiyi bilme iddiasındaki şarihlerin diğer şarihleri küçümseyici yorumları hemen dikkati çeker. Öyle ki şarihler, birbirlerini eleştirirken "bilmemiş, gâfil imiş, nâkıs imiş,

${ }^{13}$ Bursevî, Sudî́nin görüşü için "lügate muhâliftir" dese de ihtiyatlı davranır. Nitekim bir sonraki cümlede eski zaman âdetlerinden bir âdete dayanarak şarihin bu yorumu yapmış olabileceğini zikreder.

${ }^{14}$ Fusûsu'l-Hikem: Muhyiddin İbnü'l-Arabî'nin (ö. 1240) bütün fikirlerinin özeti sayılan temel eseri. Tasavvuf düşüncesinin ana kaynaklarındandır. Fusûsu'1Hikem tamlaması, "hikmetlerin yuvaları" anlamına gelir. Eser, yirmi yedi peygambere ait hikmetlere izafeten yirmi yedi bölüme ayrılmıştır (Kılıç 1996: 13, 230-237). Eserin en kapsamlı şerhleri Sofyavî Bâlî Abdullah Efendi, Abdullah elBosnevî ve son dönemde Ahmed Avni Konuk tarafından yapılmıştır.

${ }^{15}$ Sofyalı Bâlî Abdullâh Efendi (ö. 1553): İbnü'l-Arabî'nin Fusûsu'l-Hikem adlı meşhur eserinin şarihi âlim, şair ve mutasavvıf. Günümüzde Arnavutluk'a bağlı olan Usturumca'da doğdu. Öğrenimini Sofya ve İstanbul'da tamamladıktan sonra Halvetî şeyhlerinden Kâsım Çelebi'ye intisap etti. Hem zahirî hem de tasavvufî ilimlerle ilgili eserleri vardır. Şerhü'l-Fusûs isimli Arapça eserinde diğer Fusûs şarihlerinin görüşlerini değerlendirmiş, yeri geldikçe onları eleştirdiği noktalar olmuştur. 1553'te vefat etti. Kabri Sofya yakınlarındaki Salihiye kasabasındadır (Kara, 1992: 5, 20-21). 
cahil imiş, galat söylemiş" gibi bilgisizliği vurgulayıcı ifadeler kullanmaktan çekinmezler. Her şarihin kendine has bir şerh yöntemi vardır, ancak şerh sırasında birtakım hususlara değinmemek de eksiklik olarak görülmüş, ret sebebi olmuştur. Meselâ Şem î, şerhlerinde dilbilgisi kurallarına değinmeksizin daha çok anlamı vermeye gayret gösterirken, Sudî-i Bosnevî anlama ulaşmak için dilbilgisi öğelerine yoğun bir şekilde temas etmiştir. Bu sebeple Şem'î daha çok anlamla ilgili eleştiri alırken, Sudî lügat bilgisi ve dilbilgisi hususunda birtakım eleştirilere uğramıştır. Yine Şem'î eksik malumat vermesinden ötürü Sudî́nin eleştirisine uğramış, Sürurî de bazen çok detaya girmesi yahut yanlış anlam vermesi sebebiyle eleştirilerden nasibini almıştır. Dolayısıyla her şarih, hem yaptıkları hem de yapmadıklarıyla reddedilmiştir demek doğrudur. Ancak şunu rahatlıkla söyleyebiliriz ki, reddiye yapıları ve reddiyelerdeki yorumların isabeti açısından, Türk Şerh Edebiyatı'nda reddiye geleneğinin en başarılı örnekleri Sudî-i Bosnevî tarafından ortaya konmuştur.

\section{SUDÎ VE REDDİYELERI}

Türk Şerh Edebiyatı deyince akla ilk gelen birkaç isimden biri, belki de ilki olan Sudî-i Bosnevî (ö. 1600?) ${ }^{16}$ her yönüyle şarih sıfatını almaya hak kazanmış donanımlı bir âlimdir. Ömrünü şerh sahasına adamış bu

16 Sudî-i Bosnevî (ö. 1600?): 16. yüzyıl şarihlerindendir. Asıl adı Ahmed'dir. Bosna'nın Foça şehrindeki Çayniça kasabasına bağlı Sudiçi köyünde dünyaya geldi. İlk öğrenimini Foça ve Sarayova'da tamamladıktan sonra ilimde ilerlemek adına İstanbul'a geldi. Diyarbakır, Şam, Bağdat, Necef, Kûfe gibi yerleri dolaştı, buralarda dönemin değerli hocalarından başta Farsça olmak üzere çeşitli konularda dersler aldı. Sokullu Mehmed Paşa'nın (ö. 1579) sadrazamlığı zamanında tekrar İstanbul'a döndü. Atmeydanı civarında bulunan İbrahim Paşa Sarayı'ndaki has oğlanlara hoca tayin edildi. Bir süre sonra bu görevden emekliliğe ayrılmak durumunda kaldı. Hayatının geri kalan kısmında eser te'lifiyle uğraştı. Farsça Divan-ı Hafiz, Gülistân, Bostân ve Tuhfe-i Şâhidî şerhleri ile Arapça dilbilgisi kitapları Kâfiye ve Şâfiye'ye yazdığı şerhler meşhurdur.

Sudî'nin hayatı hakkında bugüne kadar pek az çalışma yapılmıştır. Bu çalışmalar içerisinde şarihin eserlerini göz önünde bulundurarak hayatı hakkında tespitlerde bulunan Nazif M. Hoca'nın "Sûdî, Hayatı, Eserleri ve İki Risâlesinin Metni, İÜEFY, İstanbul, 1980" künyeli eseri ilk sırada gelmektedir. Ayrıca bkz. (Yilmaz 2012: XLV-LIII). 
velûd kalem, son derece kuvvetli Arapça ve Farsça bilgisini "metni her yönüyle ele alma" anlayışıyla bir araya getirmeye çalışmış, bunda da büyük ölçüde başarılı olmuştur. Sudî, şerh sahasındaki bu başarısının doğal bir sonucu olarak şerhettiği eserleri başta dilbilgisi ve lügat/anlam bilgisi olmak üzere genel kültür, nüsha farkları, edebî sanatlar ve âyet-i kerime-hadis-i şerife müktesebatı bakımından incelemiş, birçok hususta ayrıntıya inme becerisini göstermiştir.

Sudî́nin reddiye anlayışının en iyi örnekleri Şerh-i Divan-ı Hafız ${ }^{17}$, Şerh-i Gülistân $n^{18}$ ve Şerh-i Bostân adlı eserlerinde görülür. Şarih, kendisiyle hemen hemen aynı dönemde yaşamış şarihleri tenkit etmiş, alana hâkimiyetini, bilgi ve becerisini reddiyeleriyle göstermiştir. Gülistân Şerhi'nde Sürurî, Şem'î, Yakub ibni Seyyid Ali, Kâfî ve Lamiî̀yi bazı hususlarda reddetmiş, bazen Farsça-Türkçe sözlüklerden Kemalpaşazade'nin Dakâyıku'l-Hakâyık'ı, Halîmî'nin Bahru'l-Garấib'i ve Nimetullâh'ın Lügat-i Nimetullâh'ını eleştirmiştir. Ayrıca Şerh-i Bostân ve Şerh-i Divan-ı Hafız başlıklı şerhlerinde de, Şem'î ve Sürurî'yi defalarca reddetmiştir. Bu itibarla, şarihin reddettiği diğer 5 şarih ve bu şarihlere ait şerhlerin dili şöyle sıralanabilir:

\section{Mevlâna Yakub bin Seyyid Ali (ö. 931/1524-25) - Şerh-i Gülistân:} Seyyid Alizade Mevlâna Yakub, ulema arasında meşhur olan Şerîatü'lİslâm isimli eserin şarihidir. Gülistân'ı Arapça şerh etmiştir. ${ }^{19}$ Bunların dişında Hâşiye-i Şerh-i Ferâ'iz li's-Seyyid Şerîf, Ecvibe 'alâ-Şerhi Miftâh liKara Seydî, Hâş̧iye-i Şerh-i Dîbâce fî̀-ilmi'n-Nahv, Hâş̧iye 'alâ-Şerhi Metâli 'i'lEnvâr gibi eserleri vardır. İmâm Yafeî'nin Mir'âtü'l-Cinân ve İbretü'lYakzân ismindeki büyük tarihini muhtasar hâle getirmiştir. Hacdan dö-

${ }^{17}$ Sudî́nin Şerh-i Divan-ı Hafız adlı eseri, Türk Şerh Edebiyatı'nın ve kendi müellefatının en güzide örneklerinden biridir. Ancak ne yazık ki -tematik değerlendirme olmaktan öte geçemeyecek birkaç çalışmayı saymazsak- eserin tamamını ortaya koyan, çeviriyazı alfabesiyle Latin harflerine aktaran ciddi bir çalışma hâlen yapılmamiştır.

${ }^{18} 2008$ yılında tarafımızca doktora tezi olarak hazırlanan eser, 2012 yılında yayınlanmiştır (Yılmaz 2012).

19 Kâtib Çelebi, Keşfü'z-Zunûn adlı eserinde, bu şerhin 16. yüzyıl şairlerinden Münîrî’ye ait olduğuyla ilgili iddiaların ortaya atıldığını söyler. bkz. (Kâtib Çelebi 1971: II, 1504). 
nerken 931/1524-25 tarihinde vefat etmiştir. Mezarının Mihaliç yahut Bursa'da olduğuna dair rivayetler vardır. (Bursalı Mehmed Tâhir 2000: II, 54).

Lami î (ö. 938/1532) - Şerh-i Dîbâce-i Gülistân (Türkçe): Nakkaş Alizade Muhammed Efendi bin Sultan Bâyezid-i Sanî hazine defterdarı Osman Çelebi bin Ali Nakkaş. Bursalıdır. Molla Camî̀nin (ö. 1492) birçok eserini tercüme ettiği için kendisine "Camî-i Rûm" denilir. Kandî'nin "Lâmi înin Hak ide rûhını şâd "mısrası ölümüne tarihtir. Bursa'da Nakkaş Ali mescidine defnedilmiştir (Tuman 2001: II, 873-874). Nefahâtü'l-Üns Tercümesi, Şevâhidün-Nübüvve Tercümesi, Şerefü'l-İnsân, İbretnümâ, Münâzara-i Bahâr u Şitâ, Münşeât, Şerh-i Mu'ammâ-yı Esmâ'ü'l-Hüsnâ, Mecma'u'l-Letâ'if, Şem' ü Pervâne, Şehrengîz-i Burusa, Gûy u Çevgân, Kıssa-i Edhem ü Hümâ, Ferhâdnâme, Heft Peyker, Vâmık u Azrâ, Hüsn ü Dil, Vîs $\ddot{u}$ Râmîn, Absâl u Salâmân eserlerinden bazılarıdır (Bursalı Mehmed Tâhir 2000: II, 493).

Muslihüddin Sürurî (ö. 969/1561-62) - Şerh-i Gülistân (Arapça), Şerh-i Bostân (Farsça), Şerh-i Divan-ı Hafız (Türkçe): Asıl adı Mustafadır. Geliboluludur. Babası oldukça varlıklı olan Sürurî Efendi, küçük yaşlarda ilim tahsil etme fırsatı bulup, usta hocalar elinde yetişmiştir. Kanuni döneminde Şehzade Mustafa'nın himayesinde bulunmuş, eserlerinin çoğunu bu sırada kaleme almıştır. Kasımpaşa Medresesi'nde ders vermekle meşgul olan Sürurî, bir süre sonra dünyanın boş olduğunu düşünüp "ölmeden evvel ölünüz" sırrına mazhar olarak Emîr Buharî tekkesi şeyhlerinden Abdüllatif Efendi'ye intisap etmiştir. Ömrünün geri kalan kısmında medresedeki görevini sürdürmüş, riyazet ve ibadetle meşgul olmuştur (Kınalızade Hasan Çelebi 1989: I, 456-457). Sürurî; Mesnevî, Gülistân ve Hafiz Divani'nı şerh etmiştir. ${ }^{20}$ Aruz ve kafiye fennine ve edebî terimlere dair Bahrü'l-Mâârif adlı eseri meşhurdur. "Mî̀

${ }^{20}$ Riyazî (ö. 1644), Riyâzü̈ş-Şuarâ adlı tezkiresinde Sürurî için “Çok müellefâtı vardur. Gülistâna ve Bostâna ve Divan-ı Hafıza şerhler yazmışdur. Zamânında Fârisîdânlık ile hayli şöhret-şiâr imiş, egerçi emsâl ü isti'mâlâtına vukûfı olmamagın çok yerde galat itmişdür (Riyazî 1071/1610: 82a-82b)" diyerek şarihin, döneminde Farsça'yı iyi bilmesiyle meşhur olduğunu, ancak Farsça'nın deyim ve atasözleri, mecazî ve kinayeli kullanımlarına vâkıf olmadığı için çok yerde yanlışa düştügüunü söylemiş, bir bakıma Sudî'nin Sürurî́ye yazdığı reddiyeleri desteklemiştir. 
reved be-behişt" ve "Gitdi cihân sürûrı" terkiplerinden anlaşlacağ 1 üzere 969/1561-62 tarihinde vefat etmiştir. Kabri İstanbul'dadır (Bursalı Mehmed Tâhir 2000: II, 225-226).

Şem î Mustafa Efendi (ö. 1011/1602'den sonra) - Şerh-i Gülistân, Şerh-i Bostân, Şerh-i Divan-ı Hafız (Türkçe): 16. yüzyılın ikinci yarısında yaşadığı bilinen Şem'î Efendi'nin ne zaman ve nerede doğduğu bilinmemektedir. Hayatı boyunca ilimle uğraşmış ve birçok öğrenci yetiştirmiş, devrin büyükleri adına şerhler kaleme almıştır. Mezarı Üsküdar'dadır. Eserleri, Şerh-i Mesnevî, Şerh-i Mantıku't-Tayr, Şerh-i Pend-i Attâr, Şerh-i Bostân, Şerh-i Gülistân, Şerh-i Bahâristân, Şerh-i Divan-ı Hafiz, Şerh-i Subhatü'l-Ebrâr, Şerh-i Tuhfetü'l-Ahrâr, Şerh-i Mahzenü'l-Esrâr, Terceme-i Şürûtu's-Salât, Terceme-i Akâid-i Lâmiyye alâ Mezhebi Mâturîdiyye ve Tuhfetü'l-Âşıkin. (Ünver 1985: 38-43), (Karavelioğlu 2005: I, 38).

Kâfî- Şerh-i Gülistân (16. yy): Sudî tarafından "Redd-i Kâfî" çıkmalarıyla eleştirilen Kâfî́nin Gülistân Şerhi hakkında ulaşabildiğimiz herhangi bir bilgi yoktur. Yaptığımız araştırmalarda eserin herhangi bir nüshasına tesadüf edemedik. Safvet'in, 18. yüzyılda Gülistân Dîbâcesine yazdığ1 şerhe ait mukaddimede "ba'ż-1 şurrāḥ rahịmehümu'llāhü'1-melikü'l-fettāḥ bu müşkili def' ve tutuḳ-1 imtinā's ref' buyurmuşlar ki şerḥ ü ta'rīfine himmet ü iḳdām ve tedḳị̣-i ma'ānīsinde diḳạt ü ihtimām idüp ez-cümle Seyyidīzāde ve Sürūrī ve Şem ī ve Kāfī ve 'ale'l-ḥuṣụs Mevlānā Sūdī her biri müstaḳillen şerḥ etmişler ve biribirinüñ išrince gitmişler ${ }^{21}$ " şeklindeki sözlerine bakılırsa Kâfî de 16. yüzyılda yaşamış Gülistân şarihleri arasındadır. Bu şarihin, 16. yüzyılda yaşamış ve Arapça kaleme aldığı şerhleriyle bilinen Akhisar/Bosnalı Hasan Kâfî (1544-1616) olma ihtimali düşünülebilir, ancak görebildiğimiz kaynaklarda Hasan Kâfî́nin böyle bir eserinden bahsedilmez.

${ }^{21}$ Safvet, Şerḥ-i Cedīd-i Dībāce-i Gülistān, SK: Serez 2559; 2a. Safvet'in buradaki şarihler arasında Kefevî Hüseyin Efendi'yi anmaması ve daha ilginci, Kefevî́nin reddettiği şarihler arasında da "Kâfî"nin olmaması akıllara Kâfî ile Kefevî'nin aynı kişi olabileceği ihtimalini getirir. Ne var ki Sudî́nin Gülistan Şerhi'nde Kâfî̀ye yönelttiği reddiyelerin varlığı ve Kefevî́nin eserini Sudî'den 6 yıl sonra 1601'de tamamlamış olması bu ihtimali zayıflatır. Yine, Sudî'nin eserin temize çekilmemiş hâlini görüp bunlar üzerinden görüş beyan ettiği düşünülebilirse de Kefevî́nin eserini Mekke'de tamamlaması ve o tarihlerde İstanbul'da olan Sudî'nin muhtemelen vefat etmiş olması bu ihtimali de neredeyse yok mesabesine indirir. 
Lütfullâh Halîmî bin Ebî Yusuf (ö. 902/ 1497'den sonra) - Bahrü'lGarâib: Farsça-Türkçe sözlük. Anadolu'da yazılmış Farsça-Türkçe manzum sözlüklerin ikincisidir. İlk bölümü sözlük, ikinci bölümü değişik konularda yararlı bilgiler ve edebî sanatlar, üçüncü kısmı aruz ve dilbilgisi olmak üzere üç bölümden oluşur (Öz 2010: 94).

Nimetullah bin Ahmed bin Mübarek er-Rumî (ö. 969/ 1561-1562) Lügat-i Nimetullâh: Farsça-Türkçe sözlük. Üç bölüm hâlinde düzenlenmiştir. Önce fiiller, sonra Farsça'nın kuralları, son bölümde de basit ve türemiş isimler ele alınır (Öz 2010: 157).

Kemalpaşazade Şemseddîn Ahmed bin Süleyman (ö. 940/1534) Dakâyıku'l-Hakâyık: Farsça-Türkçe sözlük. Kemalpaşazade bu lügati, anlam ve yazılışları birbirine yakın, eş anlamlı, eş sesli ya da zıt anlamlı Farsça kelimelerin kullanım farklılıklarını ve mana inceliklerini göstermek amacıyla kaleme almıştır (Öz 2010: 148).

Sudî́nin diğer şarihleri reddettiği hususların merkezinde dilbilgisi ve söz varlığ 1 (anlamla ilgili bahisler) vardır. Metin şerhinde, kelimelerin dilbilgisi açısından metindeki konumu, lügat anlamlarının dışında kullanılması (yan anlamlar, mecazî yahut kinayeli kullanımlar) şerhin sıhhati açısından dikkat edilmesi gereken önemli bir husustur. Sudî́nin reddiyeleri, genel itibarıyla, diğer şarihlerin dilbilgisi kurallarını yanlış değerlendirmelerinden kaynaklanan sıkıntıları, bazı anlam kusurlarını, kelimelerin lügatteki ilk manasından hareketle verilen "sı̆̆ kalmış" manaları hedef alır. Sudî'nin "reddiye"lerini,

\section{A. MUHTEVA \\ B. ÜSLUP}

olmak üzere iki ana başlık altında incelemek mümkündür.

\section{A. MUHTEVA}

Şarihin diğer şarihleri muhteva yönünden eleştirdiği reddiyeler, şu başlıklar altında incelenebilir:

1. Dilbilgisine Dair Reddiyeler

2. Lügat Bilgisine/Anlama Dair Reddiyeler

3. Belâgat Unsurları/Şekil Bilgisi/Vezin ve Kâfiyeye Dair Reddiyeler

4. İmlâya Dair Reddiyeler 
5. Sıhhatli Nüshaların Değerlendirilme(me)sine Dair Reddiyeler

6. Verilen Bilginin Yanlışlığına/Eksikliğine Dair Reddiyeler

Yukarıdaki tablodan da anlaşılacağı üzere, Sudî́nin reddiyeleri farklı konulara dayanır. Şarih, bir yandan ele aldığı metinleri ayrıntılı bir biçimde şerhetmiş, bir yandan da diğer şerhlerin eksik/kusurlu yönleriyle ilgili tenkitlerde bulunmuştur.

\section{Dilbilgisine Dair Reddiyeler}

Sudî, şerhettiği metinde geçen harf, ek, kelime ve cümleleri ses bilgisi, anlam bilgisi ve cümle bilgisi bakımından ayrıntılı biçimde değerlendirmiştir. Farsça ve Arapça kelimeleri iştikak (türetme), ek alma, izafet (muzâf/muzâfun ileyh) gibi yönlerden değerlendirmiş, bu yapıları cümle içerisindeki yer (fâiliyyet/mef'ûliyyet) ve görevleri bakımından incelemiştir. Üstelik, diğer şarihlerin bu husustaki yanlışlarını tespit etmiş, yorumlarına itirazda bulunmuş, gerekli gördüğü yerlerde görüşlerini reddetmiştir. Sudî'nin, diğer şarihleri dilbilgisi açısından tenkit ettiği örnekler, aynı zamanda şarihin dile hâkimiyetinin de açık delilidir. Şarihin dilbilgisi hususundaki reddiyelerini "Farsça Dilbilgisi Kurallarına Dair" ve "Arapça Dilbilgisi Kurallarına Dair" olmak üzere iki ayrı başlık altında incelemek gerekir.

\section{a. Farsça Dilbilgisi Kurallarına Dair Reddiyeler}

Sudî́nin dilbilgisine dair görüşleri, şerhettiği metinlerin Farsça olması, lâkin yer yer Arapça ibareler içermesi sebebiyle Farsça-Arapça dilbilgisi kuralları çevresinde yoğunluk gösterir. Şarih, ısrarla Farsça geniş zaman yapılarından her birinin bir fiil biçimine sahip olduğunu iddia eder:

"Ma'lūm ola ki Fārisìde meșādıruñ evāhiri nūndur ve nūnuñ mā-kabli tādur veyā dāldur. Ve dāluñ mā-kabli yā olursa cem̄̄́-i müştakāt andan ahz olunur kıyās-ı mutțaridle. Ammā ol iki șūretde olan meșādırdan ya'ñ̄ tālı mașdardan ve şol dāllı mașdardan ki mā-kabli yā olmaya, meșelā şüden ve būden gibi, anlardan mā̇̇ìle ism-i mef'ülden ġayrı nesne müştak olmaz. Bu üslübr żabt idince cem $\vec{\imath}-i$ 
müş̧takāt-ı 'Acem ḳıyāsī olur, hīç nesnesi semā'‘ olmaz. Nihāyeti fikre bir miḳdār riyāżet virmek gerek (Şerh-i Gülistân, 65a)".

Şarih şunu ifade eder: "Farsça'da mastar sonları "nûn" harfiyle bitmekte ve "nûn"dan önce "tâ" ya da "dâl" harfi gelmektedir. "Dâl" harfinin öncesinde "yâ" harfi varsa bütün türetmeler bu kökten yapılmalıdır. Ancak öncesinde "yâ" harfi bulunmayan ve sonu "tâ" ya da "dâl" harfiyle biten mastarlar (mesela; şüden, bûden) vasitasıyla sadece geçmiş zaman çekimi yapılıp ism-i mef' ûl (nesne ismi) türetilebilir. Kural bu şekilde ortaya konunca, Farsça'daki bütün türemiş kelimelerin kıyasî (belirli bir kural dahilinde türetilmiş) olduğu gerçeği ortaya çıkmaktadır". ${ }^{22}$ Şarihin açıkça belirttiği üzere, bugün geçmiş zaman fiil yapılarından türetildiği düşünülen Farsça geniş zaman yapıları, esasında sonu "yâ" ve "nûn" harfiyle biten geniş zaman yapılarından gelmektedir. Buna göre "kün" geniş zaman yapısı, "kerden (yapmak, etmek)" fiilinden değil "künîden" fiilinden, "ber" geniş zaman gövdesi ise fiilin "bürden (götürmek)" biçiminden değil "berîden" biçiminden türemiştir. Sudî, bu görüşüne dayanarak diğer şarihlerin kullandığı iştikak yapılarinı israrla reddeder:

Firist, fi'l-i emr-i müfred-i muhāțabdur firistīdenden, firistādenden degil (Redd-i Lāmi'ī ve Sürūrī), (Şerh-i Gülistân, $\left.18^{a}\right)$.

Āveyi, āvīḥtenden iştiḳāḳ eyleyenüñ ḳalemi sehv eylemiş (Redd-i Daḳāyıḳu'l-Hạāāyı)), (Şerh-i Gülistân, 19b).

Mekūb, fi'l-i nehy-i müfred-i muhāṭabdur kūbīdenden. Kūftenden diyenler hațā eylediler (Redd-i şurrāḥ cemīan), (Şerh-i Gülistân, 96º).

Şinev, şīnuñ kesriyle ve nūnuñ fethiyle fi'l-i emr-i müfred-i muhāṭabdur hiiṭāb-1 'āmm țarīḳıla şinevīdenden. Şenīdenden diyenler hațā söylediler (Redd-i İbn Seyyid 'Ali ve Sürūrī), (Şerh-i Gülistân, 118a).

${ }^{22}$ Şarihin bu görüşleri diğer şerhlerinde de geçmektedir. Örnek için bkz. (Hoca 1980: 38-40). 
Berī, bānuñ fethi ve rānuñ kesriyle fi'l-i mużāri'-i müfred-i muhāțabdur hițāb-1 'āmm țarīḳıla, berīdenden müştaḳdur. Bürdenden diyen ḩațā eylemiş (Redd-i Sürūrī), (Şerh-i Bostân, $\left.20^{\mathrm{b}}\right)$.

Nedārī, fi'l-i nefy-i müstaḳbel-i müfred-i muhāțabdur dārīdenden, dāştenden degül (Redd-i Şem'ī ve Sürūrī), (Şerh-i Bostân, 103').

Āy, fi'l-i mużāri'-i müfred-i muhāṭabdur āyīdenden, gelürsin dimekdür. Āmedenden diyen sehv eylemiş (Redd-i Sürūrī ve Şem $̄ \overline{1})$, (Şerh-i Bostân, 132a).

Āsāyiş, ism-i mașdardur āsāyīdenden. Āsūdenden diyen sehv eylemiş (Redd-i Şem'ī ve Sürūrī), (Şerh-i Bostân, 257b).

Bidūzed, fi'l-i mużāri'-i cem'-i ġā'ibdür dūzīdenden. Dikerler ya'nī mihlarlar dimekdür. Dūhtenden diyen sehv eylemiş. (Redd-i Şemī ve Sürūrī), (Şerh-i Bostân, 431'b).

Şarihin sürekli üzerinde durduğu bir başka konu "mâziden kısım" meselesidir. Sudî, kendisinin türettiği "mâziden kısım" terimini, Gülistân Şerhi'nde Farsça "resîde (varmış, ulaşmış)" kelimesinden hareketle açıklar. Bu kelimenin diğer şarihlerin sandığı gibi ism-i mef'ûl değil, "mâziden kısım" olduğunu söyler. İsm-i mef'ûl, nâ'ib ani'l-fâilin yani meçhul yapıların yüklemidir; "mâziden kısım" adını verdiği yapı ise, fâilin yüklemi görevindedir. Şarih, bu tür sîgaları "mâziden kısım" olarak adlandırıp, bu hususta farklı yorumda bulunan diğer şarihleri hemen her firsatta reddetmiştir:

Bārān-ı raḥmet-i bī-hisābeş heme-rā resīde: Resīde, irişmiş dimekdür. "İsm-i mef'ūldür resīdenden" diyenler mülāḥaẓasuz söylemişler (Redd-i Lāmi'ì ve Sürūrī). Zīrā ism-i mef'ūl oldur ki nā'ib 'ani'l-fā'ile müsned ola. Bu ise fāiline müsneddür. Pes ism-i mef'ūl olmag̉a ḳābil degül. Nihāyeti șìga ism-i mef'ūlle müşterekdür. İmdi bunuñ gibi șịgalara "māżīden ḳısım" deyü tṭlāḳ eylesek vechden ḩālī degül. (Şerh-i Gülistân, $3^{\text {b) }}$.

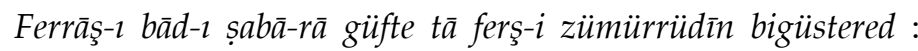
Güfte, bunda māżīden ḳısımdur sibāk u siyāḳ-1 kelām muḳteżāsıyla. İsm-i mef'ūl degüldür ba'żılar zann eyledügi gibi (Redd-i Lāmi'ī ve Sürūrī). 'Ale'l-ḩuṣūṣ ki “ism-i mef'ūldür ve 
ḳā'ili Allāhdur" diyen garāīb söylemiş (Redd-i Şemīi), (Şerh-i Gülistân, $\left.4^{\mathrm{b}}\right)$.

Meber hācet be-nezdīk-i turuş-rūy/ Ki ez-h̄ūy-ı bedeş fersūde gerdī : Fersūde, lüğatde aşınmış ma'nāsınadur, māżīden ḳısımdur. Ammā isti'mālde iżțıāb ve bī-ḥużūrlık ma'nāsınadur. Bunuñ gibi șịgaları ism-i mef'ūl ıṭlāḳ idenlerüñ tetebbu' 1 yoḳmış (Redd-i Sürūrī), (Şerh-i Gülistân, 129a-129b).

Farsça dilbilgisi kurallarına dair eleştirilerin bir kısmı da terkip/izâfet yapılarındaki tutarsızlıklarla ilgilidir. Diğer şarihlerin izafet olmayan yerde izafet göstermeleri yahut izafet ve terkip yapılarına dair yanlış hüküm vermeleri Sudî'nin dikkatinden kaçmamış, onların yanlışlarını düzeltmeye çalışmıştır:

Bir vechle dahı ma'nāyı taḳīr idüp dir ki: "Dahı bu beytleri kendi hạ̄lüme münāsib eydürdüm. Bu taḳdīr üzre beythā lafł̣ı münāsib lafẓına mużāf olmaz" dimiş. Pes bu ḳayddan ma'lūm oldı ki evvelki taḳrīrinde beythā lafẓını münāsib lafł̣ına mużāf idermiş. Eger böyle ise yaramaz idermiş (Redd-i Şem $1 \overline{1})$, (Şerh-i Gülistân, 17a).

"Fārisīde mevṣūf șıfatına mużāf olmaḳ cā'iz degül" diyenler meydān-1 Fürsüñ fārislerinden degül imiş (Redd-i Seyyid 'Ali ve Kāfī ve Sürūrī), (Şerh-i Gülistân, 64a).

Huarānı bār-ber-dāra ve ādemiyānı merdüm-āzāra iżāfet eylemeyen ya'nī iżāfetlerin tecvīz eylemeyen Fārisīde başg̉a bir șāhịib-i mežheb imiş (Redd-i Kāfī), (Şerh-i Gülistân, 64º).

Kelīmī ki çarh u felek Ṭūr-ı ūst: Çarhı felege iżāfet idenler hațā eylemişler (Redd-i Sürūrī ve Şem īi), (Şerh-i Bostân, 23b).

Dest-renc, terkīb-i mezcī. El imegi dimekdür. Terkīb-i iżāfī țutan muhālif söylemiş. (Redd-i Şem'ī), (Şerh-i Bostân, 345a).

Fālı ferdāya iżāfet eyleyen istiḳāmet-i ma'nādan gaāil imiş (Redd-i Sürūrī), (Şerh-i Divan-ı Hafız, III, 37).

Sudî́nin şerhinde dikkat ettiği noktalardan biri de Farsça harf ve eklerin yapı ve görevleridir. Şarih, bu tür Farsça yapıların yerinde kullanılıp kullanılmamasını bir hayli önemsediği için, yeri geldikçe diğer şarihlerin yaptığ 1 yanlışlara temas eder: 
Gār, kāf-1 'Acemle edāt-1 mübālag̉adur. "Ṣīga-i māżīnüñ āhhirine lāḥık olur, mübālag̉a-i fā'il ma'nāsına. Perverdigār gibi Rabb ma'nāsına ve Āferīdgār gibi Huallāk ma'nāsına. Ve gāh olur ki emr șịgası āḩirine lāḥı̣ olur Āmurzgār gibi Ġafūr ve Ġaffār ma'nāsına ve Āmūzgār gibi keșīrü't-te'allüm ve keșīrü'tta 'līm ma'nāsına" diyen ziyāde ḩațā söylemiş. Zīrā gār, fi'le hergiz dāhil olmaz. Ve bu zikr eyledügi elfāz esmā-i meșādırdur, efāl degüldür. Ve virdigi ma'ānīden de ismiyyetleri ma'lūmdur (Redd-i Lāmi'ī), (Şerh-i Gülistân, 7b).

Mu'avvel, ism-i mef'ūldür, tef'̄ill bābından. I'timādsuz dimekdür. Bī-mu'avvel diyen hațā eylemiş. Zīrā bì, esmā'-i cevāmide ve esmā'-i meșādıra mahșūușdur, müştakāa dāhil olmaz (Redd-i Şem $\overline{1})$, (Şerh-i Gülistân, 104a)

"Hemzeler hiiṭāb içündür" diyen ḳābil-i hiițāb degül imiş (Redd-i Şem $\left.{ }^{\mathrm{i}}\right)$, (Şerh-i Gülistân, 131ª).

Der, harf-i șiladur, bā ma'nāsina. Harf-i ẓarf țutan sehv eylemiş (Redd-i Şem'ī), (Şerh-i Bostân, 25b).

Ber, ḥarf-i zarf. Harf-i isti'lā țutan bilmezmiş (Redd-i Şem '̄i), (Şerh-i Bostân, 249a).

Ki ḥarfini edāt-1 ta'līl țutan ma'lūl țab' imiş (Redd-i Şem'î), (Şerh-i Divan-ı Hafiz, II, 359).

Sudî́nin reddettiği dilbilgisi hususlarından biri de fiilin kipi ve çatısını yanlış tayin etmekten kaynaklanan kusurlardır. Buna göre şarih, fiil kip ve çatılarını müteaddî (geçişli) - lâzım (geçişsiz), malûm (etken) mechûl (edilgen), mâzî (geçmiş zaman) - muzâri (geniş zaman) olma durumlarına göre değerlendirip, diğer şarihlerin bu husustaki yanlışlarını reddetmiştir:

Bireftend: Bā, harf-i te'kīd. Reftend aṣlında refteenddür, żarūret-i vezn içün hā-yı resmile hemze-i müctelibe sāḳṭ olmışdur. Zīrā edāt-1 haberüñ müfredi ve cem'i isme dāhil olur, fi'le dāḩil olmaz. Niteki bu şerḥde tekrār zikr olundı. Pes fi'l-i māżì olmasını tecvīz eyleyen mežkūr ḳāiideyi bilmezmiş (Redd-i Şem $\left.{ }^{(}\right)$), (Şerh-i Bostân, 22a). 
Sūhnt, bunda lāzımdur. Müte'addī diyen lāzımla müte'addī ma'nāsını teşhīṣ eylemezmiş (Redd-i Sürūrī), (Şerh-i Bostân, 374 a).

Bimālīdi, bunda mechūldür diyen ma'lūmı mechūlden farḳ eylemezmiş (Redd-i Şem $̄ ̄)$ ), (Şerh-i Bostân, 377a).

Efrūhnt, fi'l-i māżī-i müfred-i gà̄'ib; yalıñlatdurdı. Bunda müte'addī vāḳi` olmış. Lüzūmın tecvīz eyleyen mā-lā-yecūzı iltizām eylemiş (Redd-i Şem $̄ ̄)$, (Şerh-i Divan-ı Hafiz, II, 134).

\section{b. Arapça Dilbilgisi Kurallarına Dair Reddiyeler}

Şarihin, Arapça dilbilgisi kurallarına dair reddiyeleri; fiil çekimleri, fâ'iliyyet-mef' ûliyyet ilişkisi, masdariyyet, mübtedâ-haber ve ek konuları etrafında yoğunlaşmıştır. Mesela aşağıdaki örnekte, "vülât" kelimesinin vezniyle ilgili bir dilbilgisi hususiyeti üzerinden Lamiî̀yi reddetmiş, reddetme sebebini ayrıntılı biçimde açıklamıştır:

Vülāt, vālīnüñ cem'idür; hākimler dimekdür. Ma'lūm ola ki šülās̄ī mücerredüñ nāḳıṣından ism-i fā'ilüñ cem'-i mükesseri bu minvāl üzre gelür. Kaạ̣innüñ kuḍāt ve rāmīnüñ rumāt ve ḥāmīnüñ humāāt geldügi gibi. Aṣlı veleyetün ve ḳaẓayetün ve remeyetün idi nașaratün vezni üzre. Pes yā müteharrik ve māḳabli meftūḥ olduğ1-y-çün elife ḳalb eylediler, velāt ve ḳażāt oldı fānuñ fethiyle. Pes ḳanāt misillī müfredelere mültebis olmasun diyü fāyı mażmūm idüp vülāt ve kużāt didiler. Vezinleri fu'letu ün vezni üzredür. İmdi "fu’ātün vezni üzre gelür" diyen eyle zạn eylemiş ki lāme'l-fi'l elife ḳalb olmaġ-la lāme'l-fi'l olmaḳdan çıḳar. Şöyle zann olunur ki bu ḳā'il evzān-1 tașrīfiyyeden āgāh degül imiş. 'Afā'allāhü 'an-hü (Redd-i Lāmi'î), (Şerh-i Gülistân, 13-14a).

Aşağıdaki örnekte ise Arapça bir beyitte geçen "hâvi" kelimesini "müfâale" bâbının mazisi sanıp, kelimenin ism-i fâil olduğunu tayin edemeyen Şem' '̂̀'yi eleştirir:

İżā şeba'a'l-kemiyyü yeșūlu baţ̦sā / Ve hāovi'l-baṭni yabțışu bi'lfirāri : Mıșrā'-1 șānīde ism-i fā'il yerine müfā'ale bābından fi'l-i māżì īrād eyleyen ve bațni lafẓını aña merfū' fā'il țutup $i z \bar{a}$ hāve'l-baṭnu taḳdīr iden kendi zu'mıyla taḳdīr eylemiş. Zīrā bu 
lügat müfā'alede müsta'mel degül (Redd-i Şem'ī), (Şerh-i Gülistân, 52a).

Kelime türetme (müştak) kurallarıyla ilgili eleştirileri de vardır. Gülistân Şerhi'nde geçen aşağıdaki örneklerin ilkinde "mücâveret" kelimesini "civâr" kelimesinden alıp mastarı mastardan türetenleri eleştirmiş, ikincisinde ise "ledga (akrep 1sırı̆̆ı)" kelimesine mastar anlamı verenleri reddetmiştir:

Mücāveret, müfā'ale bābından mașdardur civār gibi ki mașdar-1 șānīsidür. Pes "mücāveret, civārdan müştaḳdur" dimek hemān mașdar mașdardan müştaḳdur dimekdür. Bu ise kelām-1 lag̀vdur (Redd-i İbn Seyyid 'Ali ve Sürūrī), (Şerh-i Gülistân, 205).

Ledġa, lāmuñ fethi ve dāluñ sükūnıla aṣlında 'aḳreb ṣoḳdısına dirler. Maṣdar ma'nāsı virenler iṣābet eylememişler Zīrā mașdarı ledǵ ve tildāg gelür (Redd-i İbn Seyyid 'Ali ve Sürūrī), (Şerh-i Gülistân, 212b).

Yine, aşağıdaki örneklerin ilkinde, tef'îl bâbından ism-i fâil olan muhassıl kelimesini, müfâale bâbından ism-i fâil olarak değerlendiren Şem'î ve Sürurî'yi, ikincisinde ise if'âl bâbından ism-i fâil olan mün'im kelimesini ism-i mef'ûl sanan Şem' '̂̂́yi reddeder:

Muhạaṣıll, ism-i fā'ildür tef'îl bābından, bir nesneyi taḥ̣̂il idici ma'nāsına. Muhạạṣl diyüp müfā'ale bābından țutanlar ehl-i tahșīl degüller imiş (Redd-i Sürūrī ve Şem'ī), (Şerh-i Divan-ı Hafiz, II, 410).

Mün'im, if'āl bābından ism-i fā'ildür șāḥib-i ni'met ma'nāsına. İsm-i mef'ūl ma'nāsına ahž eyleyen bilmezmiş (Redd-i Şem $\left.{ }^{(}\right)$), (Şerh-i Bostân, 369').

\section{Lügat Bilgisine/Anlama Dair Reddiyeler}

Sudî, şerhlerinde, metni oluşturan hemen her isim, sıfat, zamir, fiil, zarf ve edatı, bulunduğu konum ve göreve göre değerlendirmiş, böylece lügatte birden fazla anlama sahip bazı kelimelerin uygun olmayan anlamını kullanmak gibi bir yanlışa düşmekten kaçınmaya gayret göstermiştir. Buna göre kelimenin "metindeki anlamı"nı yakalamaya gayret 
gösterir. Böylesi bir tutuma bağlı olarak, diğer şarihlerin yanlış anlamalarına itirazda bulunur. Şarihin, diğer şarihlerin metindeki kelime veya kelime grupları için yaptıkları değerlendirmelerle ilgili eleştirilerini iki başlık altında incelemek mümkündür:

a. Kelime veya kelime gruplarına verilen yanlış anlamlar: Sudî, metinde geçen herhangi bir kelimenin, metin içerisindeki yerine göre mecazî ve yan anlamları düşünülmeksizin lügatteki ilk anlamının verilmesini reddeder. Bazen tek bir kelimenin anlamıla ilgili reddiyede bulunur, bazen de bir kelime öbeğinin yanlış anlamlandırılmasını eleştirir. Mesela, "kasabü'l-habîb (sevgiliye gönderilen şeker kamışından yapılmiş sepet)" ifadesini,

“Kașabü'l-ḥabīb oldur ki şeker ḳamışını huurde dog̉rarlar ya'nī iki boġum ortasını uvaḳ uvaḳ keserler. Andan șoñra ol pāreleri takş̧īr iderler ya'nī ḳabuğını șoyarlar. Ve bir țabak içine tertīb iderler ve tezyīn iderler, bu yerler ya'nī İslāmbolda meyveyi sellelere tertīb ü tezyīn eyledükleri gibi. Andan șoñra üzerine gülāb ve bahūr șuyı seperler ve dostlar biribirine irsāl iderler. Pes bu üslūbda gönderilen şeker ḳamışına ḳașabü'lhabīb dirler (Şerh-i Gülistân, 10º."

şeklinde açılar. Bu tabiri anlamayan diğer şarihlerin "uzun uzadıya ve boşa" yorum yapmasını eleştirerek, bunları okumanın baş ağrısı meydana getireceğini şöyle ifade eder:

Kașabü'l-ḥabīb 'ibāretinde ekṣer-i şurrāhuuñ mufașșal u muṭavvel mālā-ya'nīsine iltifāt olınmasun ki șudā' īrās ider (Redd-i İbn Seyyid 'Ali ve Lāmi'ī ve Sürūrī ve Kāfī), (Şerh-i Gülistân, 10 $)$.

Sudî́nin, kelime ve kelime öbeklerinin yanlış değerlendirilmesine dair reddiyelerine aşağıdaki örnekleri vermek mümkündür:

İnbisāț, infi'āl bābından maṣdardur. Bunda küstāhnāne dimekdür. "Mülāțafe ve mizāḥ țarīkıyla" diyenler maḥalle münāsib söylememişler. Zīrā mürīd şeyhinden kerāmet dilemek küstāhlıḳdur, 'ale'l-huuṣūṣ ki mizāḥ țarīḳıla (Redd-i Şem'ī ve Kāfī), (Şerh-i Gülistân, 8b-9a). 
Nemānd lafł̣ını fevt oldı ma'nāsında isti'mālleri şāyi'dür. Türkīde ba'żı yerlerde fevt oldı diyecek yerde "ḳalmadı" dirler. Pes, "dünyāda kalmadı" diyen bu isti'māli bilmez imiş ki "dünyāda" lafẓını taḳdīr eylemiş (Redd-i Şemī), (Şerh-i Gülistân, 34a).

Āvīht, fi'l-i māżīi mechūldür. İbn Seyyid 'Ali og̉ll, Sürūrīye iftirā idüp "fi'l-i māżì-i ma'lūm didi" dimiş ve bu vechle ta'arruż eylemiş. Līkin ikisi bile iṣābet eylememiş. Zīrā āvīhnt bunda yapışdı ma'nāsına, aṣıldı ma'nāsına degül. Āvīhnt bunuñ gibi yerlerde, yapışdı dimekdür (Redd-i İbn Seyyid 'Ali ve Sürūrī), (Şerh-i Gülistân, 44b).

Sa'y, yürimege dirler. Bunda sa'y, "kūşiş" ma'nāsına aḩz eyleyen eyi lügate sa'y eylememiş (Redd-i Şem'ī), (Şerh-i Gülistân, 87b).

Güsiled, kāf-1 'Acemüñ żammı ve kesriyle ve sīnüñ fetḥi ve kesriyle güsilīden maṣdarından fi'l-i mużāri'-i müfred-i gā’ib; üzer ve ḳırar dimekdür. Meșelā ip veyā iplik ḳırmak gibi. Kaṭ̂'-1la ta'bīr idenler hațā eylediler (Redd-i cemī'an şurrāḥ), (Şerh-i Gülistân, 100-101'a).

Bunda semā', șavt ü āvāz ma'nāsına olduğı ziyāde bedīhīdür. Pes semā' șūfīler raḳṣı ma'nāsına ve istimā' etmek aḩz idenler bu ma'nāyı bilmezlermiş (Redd-i Şem'ī ve Sürūrī), (Şerh-i Gülistân, 101ª-101b).

Ebrū-yı kūr beyāniyyedür. Zīrā bunda kūr, 'adem-i ebrūdan 'ibāretdür. A'mā ma'nāsına degül. Ya'nī ebrūnuñ ḳılı olmayınca ebrūya rastık çekmek fā'ide virmez. Şurrāḥ kūruñ bu ma'nāsina ta'arruż eylemedüklerinden ma'lūmdur ki kūrı a'mā ma'nāsına aḩz iderler (Redd-i şurrāḥ cemī'an), (Şerh-i Gülistân, 140).

Ber-nişesten, biñdi dimekdür. Zīrā ber-nişesten biñmekdür ata ve gayrıya. Pes "yuḳarı oturdı" diyen isti'māli bilmezmiş (Redd-i Şem ī), (Şerh-i Bostân, 25a).

Bigüft ey hudāvend-i İrān u Țūr / Ki çeşm-i bed-i rūzgār ez-tï $d \bar{u} r: \ldots$ İrān kesr-i hemze ile ve sükūn-1 bā-y-ıla Ceyhụn 1rmaġından ötesine ve añarısına dirler. Ve Tūr, tānuñ żammı ve 
sükūn-1 vāv-1la ve Tūrān Ceyhūnuñ berisine dirler. Pes Īrān u Tūr, 'Arab u 'Acem diyen bilmezmiş (Redd-i Şem̄i)), (Şerh-i Bostân, 113a).

Bes, bā-yı 'Arabuñ fethiyle yeter dimekdür. Bā-yı 'Acemle șoñra ma'nāsına diyen hațā söylemiş (Redd-i Sürūrī ve Şem'ī), (Şerh-i Bostân, 443b).

Sefīne, cönk cinsinden bir nev'dür ki bu zamānda ziyāde şüyū' üzredür. Ammā bunda dīvān murāddur... Bu beytde sefīneyi gemi ma'nāsına aḩz eyleyen sefīneden ḩaber-dār degül imiş (Redd-i Sürūrī ve Şem'ī), (Şerh-i Divan-ı Hafiz, II, 132-133).

Minhüsinde Aras, arż-1 Rūma ḳarīb bir şehrüñ ismidür diyen Arası bilmez imiş. 'Alā külli ḥāl bir șuyuñ ismidür (Redd-i Şem'ī), (Şerh-i Divan-ı Hafız, II, 236).

Semen-sā, vașf-1 terkībīdür, sāyīdenden, ezmek ve sürtmek ve sürtünmek. Rūy-ı cānānı semene ya'nī ak güle teşbīh iderler ve zülfüñ aña sürtünmesini semen-sā-y-1la ta'bīr iderler... Mıșrā'-1 șānīnüñ ma'nāsını "hem benüm göñlüm meşāmı senüñ semen maḥv idici zülfüñden hoş" diyen ve "hem meşām-1 dilüm senüñ semen rāyihạalu zülfüñ̃den hoş" diyen semen-sānuñ ma'nāsını bilmez imiş (Redd-i Sürūrī ve Şem̄i), (Şerh-i Divan-ı Hafız, II, 345-346).

b. Çeviri hatalarından doğan eksik ve kusurlu anlamlar: Sudî'nin reddettiği hususlardan biri de, kelime ve kelime öbeklerini yanlış değerlendirme sonucu ortaya çıkan eksik ve kusurlu anlamlandırmalardır. Özellikle Divan-ı Hafız şerhinin birçok yerinde Sürurî ve Şem' '̂̂'yi 'eksik ve kusurlu anlam verme' açısından eleştiren şarih, Bostân ve Gülistân şerhlerinde de benzer eleştirilerde bulunmuştur. Diğer şarihlerin gerek dilbilgisi öğelerini layıkıyla değerlendirememesi gerekse anlam vermede isabetli tercih yapamaması, şerhedilen parçanın bütün anlamını etkilemiştir. Böylece meramı ifade etmekten uzak anlamlar ortaya çıkmıştır. Mesela, aşağıdaki örnekte Şem'î, Farsça iyelik III. teklik şahıs zamiri "eş"i yanlış yerde değerlendirmek suretiyle bir dilbilgisi hatasına düştüğü için, istemeyerek de olsa "Hz. Lût" yerine karısını peygamber göstermiştir: 
Bā-bedān yār geşt hem-ser-i Lūṭ / Hōnedān-ı nübüvveteş güm şüd: Nübüvveteş żamīrini hemsere ircāc idüp ma'nāsını "ol hatunuñ nübüvveti hānedānı żāyi` oldı" diyen ḩatuna nübüvvet issbāt eylemiş. Bu hod cā'iz degül (Redd-i Şem $\left.{ }^{c} \mathbf{1}\right)$, (Şerh-i Gülistân, 39a).

Benzer başka örnekler de vardır. Şarihe göre "şebpere (yarasa)" kelimesinin geçtiği aşağıdaki beyitte, diğer şarihler anlamı karıştırmış, söz öbeğini doğru anlamadıkları için genel anlamı da uygun biçimde verememişlerdir. Sudî, diğer şarihlerin verdiği yanlış anlamları sırasıyla reddeder:

Ger nebīned be-rūz şeb-pere-çeşm / Çeşme-i āftāb-rā çi günāh: Eger yarasa gözli olan kimse gündüzi görmezse āftāb çeşmesinüñ ne günāhı var. Ya'nī ol şahșuñ gündüz görmedügi āftābuñ ḳuṣūrından degüldür, belki kendinüñ ol marażındandur. Bunuñ taḳdīrini çeşm-i şebpere eyleyen vașf-1 terkībīden āgāh olmaduğından terkīb-i iżāfiyyeyi irtikāb eylemiş (Redd-i İbn Seyyid 'Ali). Ve "eger rūzda şebperenüñ gözi görmeye" diyen de išrince gitmiş (Redd-i Şem'ī). Miṣrā'-1 șānīnüñ ma'nāsını "āftāb çeşmesinüñ ne günāhı var, zīrā bu ḳabāḥat şemsden degüldür belki yarasanuñ kendüsindendür" diyen mișrā'-1 evvelde eyledügi hațāyı te'yīd eylemiş (Redd-i Şem'ī). Ba'ż-1 şurrāḥ şebpere 'ibāretinüñ aṣlı perendedür dimiş ve ba'żıları redd idüp şebpere aṣl-1 vaż' üzre lügatdür dimiş. Ve ba'żısı haḳk budur ki şeb-perendeden me'hūz olmaġa mānic yoḳdur dimiş. Līkin hạḳ budur ki üçi bile iṣābet eylememiş. Zīrā așlında pereng-i şebdür sā'ir müştaḳātdan olan vaṣf-1 terkībīler gibi (Redd-i İbn Seyyid 'Ali ve Sürūrī ve Kāfī). Şebpere-çeşmüñ ma'nāsını "ey 'aynuhū" diyen ma'lūmdur ki iki evvelki gibi vașf-1 terkībīden āgāh olmamış (Redd-i Sürūrī), (Şerh-i Gülistân, $\left.41^{\mathrm{b}}-42^{\mathrm{a}}\right)$.

Aşağıdaki örnekte ise, "ez-helâket çîzî nemânde bûd" yapısına verilen anlamları tenkit eder. Sudî'ye göre anlam "bir adam boyu suda helâk olmana nesne kalmamıştı, yani ölmene ramak kalmıştı" şeklindeyken İbn Seyyid Ali ve Sürurî doğru manayı verememiştir:

Yād dārem ki ber-rūy-ı deryā-yı mağrib mī reftī ve kademet ter nemī şüd ve imrūz der-īn yek kầmet āb ez-helāket çīzì nemānde būd. 
Yādumdadur ki sen deryā-yı mağrib yüzinde giderdüñ ve ayag̉uñ yaş olmazdı ya'nī ș̣lanmazdı ve bugün bir ādem boyı șuda helākden nesne ḳalmamışdı. Hāṣılı gark olayazduñ... Ezhelāket çīzi nemānde būduñ ma'nāsinı ġayr ez-helāket taḳdīr iden ma'nāyı helāk eylemiş (Redd-i İbn Seyyid 'Ali). Ve "küllī helāküñ bölündi ve andan bir cüz' ve bir pāre aṣlā ḳalmadı" diyen 'aceb ma'nā tașvīr eylemiş (Redd-i Sürūrī), (Şerh-i Gülistân, 91'b-92a)

Bir başka örnekte, Arapça bir beytin anlamı hususunda diğer şarihlerin tamamını mizahî bir dil ile tenkit eder:

Yü'eccicu nāran șümme yutfī bi-reşşetin / Li-żāke terānī muhrakan ve ġarīkā : Cānān āteş-i 'aşk u mahabbeti tecellī sebebiyle îkād idüp yalıñlandurur ya'nī cemālini göstermekle 'aşk āteşini peydā ider. Șoñra istitār u ihtifā reşāşıyla șöyündürür. Hāṣılı te'cīc, nār-1 tecellīden kināyetdür ve reşāşla 1ṭfā tesettür ü iḩtifādan. Yánī kendini cānān-1 ezel 'āşı̣ u muhibbine gösterür șoñra gizler... Mıșā̄o'-1 evvelüñ ma'nāsını "firāḳında beni 'aşḳı āteşine yaḳar șoñra vișāl șuyınuñ serpindisiyle o āteşi șöyündürür" diyen ma'nā-yı beyti șoyundurmış (Redd-i Şem'ī). Ve mıșrā'-1 evvelüñ ma'nāsını "aşk nārını îkād ider firāḳdan bir nev'-ile, andan șoñra mā'-i vișālden bir reşşe ile anı șoyundurur" diyen mezkūr ma'nā-yı mıșrā'ı șoyundurmış (Redd-i İbn Seyyid 'Ali). Ve "nār-1 'aşḳ̂ cānān te'cīc ider, andan șoñra viṣālüñ azacuk șuyıyla șoyundurur" diyen mezkūrlar gibi te'cīc ü iṭ̂āa ziyāde ibhām buyurmış (Redd-i Sürūrī), (Şerh-i Gülistân, 93a).

Aşağıdaki örnekte, Farsça "pîş" kelimesini "kat" yerine "ön" manasına alan Şem'î beyti anlam bakımından yanlış değerlendirmiştir. Sürurî, "dest tüvân kerd der-âgûş̧-1 hîş (elin seni kucaklayabilir)" yapısını "eli etmek olur kendi kucağında" ve Şem’î "elini kucaklayıp yatmak mümkündür" biçiminde çevirerek kusurlu anlamlar vermiş, bu durum Sudî tarafından yine alaycı bir edayla reddedilmiştir:

Ver nebüved dilber-i hem-ḩ'ābe pīş / Dest tüvān kerd der-āğ ūş-l h̆'îş : Pīş bunda, ḳat ma'nāsınadur. Pīşi bunda öñ ma'nāsına alup ma'nāsı "eger bir döşekde öñinde bile yatur dilber olmaya" diyen dilberi çirkin yaturmış (Redd-i Şem̄î)... Mıșrā'-1 
șānīnüñ Türkīce ma'nāsı "eli itmek olur kendi ḳuçmag̉uñda" diyen tırzīk ma'nā ḳuçmaḳda 'aceb hüneri var (Redd-i Sürūrī). Ve "elini kendi ḳucaġında eylemek mümkindür ya'nī elini ḳuçup yatmaḳ" diyen išrince gitmiş (Redd-i Şem'ī). 'Afa'llāhü 'an-hümā (Şerh-i Gülistân, 152a-152b).

Yine, Farsça "tünd (ani, hızlı)" kelimesinin yanlış anlamlandırılması sonucu İbn Seyyid Ali ve Sürurî beyti doğru anlayamamış, anlamda kusur etmişlerdir. Sudî’nin bu yanlışa reddiyesi şöyledir:

Be-tündī sebük dest bürden be-tīg / Be-dendān bered püşst-i dest$i$ dirìg : Hiddetle fevrī ḳılıca el iltmek ya'nī el șunmak hayf ve peşīmānlık eli arḳasını dişine ildür. Hāṣılı ol hâaleti eylemek hayflanup ve peşīmān olup el arḳasını dişine ildür. İsnād mecāzīdür... Mıṣrā'-1 evvelüñ ma'nāsını "der-zamān-ı düşvārī vü żucret dest-be-tīg bürden be-şitāb u isti'cāl" diyen ma'nāyı düşvār eylemiş (Redd-i İbn Seyyid 'Ali). Ve "ṣarplığla eli yeyni iltmek ḳılıca" diyen ma'nāyı șarp yere çekmiş (Redd-i Sürūrī), (Şerh-i Gülistân, 181²).

Bostân Şerhi'nden seçtiğimiz aşağıdaki örnekte, "salât" ve "selâm" kelimelerinin alâ harfiyle birlikte "senin üzerine olsun" değil "sana lâyık ve mahsustur" anlamina geldiğini söyleyip Şem'î̀nin verdiği "üzerine olsun" manasinı reddeder:

Çi na't-ı pesendīde gūyem türā / 'Aleyke's-selām ey nebiyye'lverā: Ma'lūm ola ki șalāt u selām 'alā ḥarfiyle müsta'meldür. Ammā ma'nāsı senüñ üzerine olsun dimek degildür, belki senüñdür ve saña lāyık u mahșūṣdur dimekdür. Pes "selām senüñ üzerine olsun" diyen selām eylememiş olur (Redd-i Şem īi), (Şerh-i Bostân, 27a).

Konuyla ilgili son örnekleri Şerh-i Divan-1 Hafız'dan veriyoruz. Hafız'in anlaşılması zor beyitlerini ustalıkla şerheden Sudî, anlamı bulmakla kalmayıp diğer şarihlerin yanlışlarını da düzeltir:

Rūy u riyāda olan rūy 'yüze söylemek' ma'nāsına diyen kimse 'aceb bunı ne yüzle söyledi (Redd-i Sürūrī), (Şerh-i Divan$\imath$ Hafiz, I, 266).

Hoş birānīm cehān der-nazar-ı rāh-revān/ Fikr-i esb-i siyeh $\ddot{u}$ zīn-i muġarrak nekünīm... Yolcılar naẓarında ḳalḳıyı ḳalḳıyı gü- 
zel sürelüm ya'nī ehl-i sülūk naẓarında eyüce sülūk idelüm... Mıșrā'-1 evvelüñ ma'nāsını "hoş sürelüm segürdici yolcılar naz̧arında" diyen eyüce segürdememiş. (Redd-i Sürūrī), (Şerh-i Divan-ı Hafiz, III, 93).

Şebì dil-rā be-tārīki zi-zülfet mī cüstem... Bir gice göñlümi zülfüñ ḳarañlığında arardum... Mıșrā'-1 evvelüñ ma'nāsını "bir gice göñli ḳarañuluḳda senüñ zülfüñ istedüm" diyen ve "bir gice ḳarañuluḳda göñlümi senüñ zülfüñden istedüm" diyen ya'nī "almag̉a ḳaṣd eyledüm" diyenler lafł̣ı da manāyı da eyü alamamışlar (Redd-i Şem'ī ve Sürūrī), (Şerh-i Divan-ı Hafız, III, 101-102).

\section{Belâgat Unsurları/Şekil Bilgisi/Vezin ve Kâfiyeye Dair Reddiyeler}

Bazı şarihler, ele aldıkları metni anlam ve muhteva unsurları yönünden değerlendirirken, belagat, şekil bilgisi, aruz ve kafiye açısından da birtakım tespitlerde bulunurlar. Sudî, şerhlerinde bu anlayışı gözeten şarihler arasındadır. Şarih, şerhettiği eserlerde geçen söz ve söz öbeklerini, başta edebî sanatlar olmak üzere nazım şekli, nazım birimi, ölçü ve kafiye yönünden incelemiş, bu husustaki görüşlerini ortaya koymuştur. Dahası, diğer şarihlerin bu husustaki bazı tutumlarını eleştirmiş, yeri geldikçe onları hafife alıcı ifadelerle reddetmiştir. Şarihin bu konudaki reddiyelerini yine başlıklar hâlinde incelemek gerekir.

\section{a. Belâgat Unsurlarının Yanlış Kullanımına Dair Reddiyeler}

Belâgat ilmi fesahat, maanî ve beyan ilimlerini de kapsayan geniş bir alandır. Sudî'nin belagat unsurlarının yanlış kullanımına dair reddiyelerinin merkezine, "1tnâb (sözü gereksiz yere uzatmak)" hususundaki eleştirilerini yerleştirmek mümkündür. Bir belâgat terimi olarak "1tnâb", "çok sözle az mana ifade etmek, kısacası sözü uzatmak (Tâhirü'l-Mevlevî 1994: 76)" anlamina gelir. Sudî, bir metnin kısa ve öz şerhedilmesi, bunun sonucunda yalnızca gerekli bilgilerin verilmesi taraftarıdır. $\mathrm{Bu}$ yüzden, diğer şarihlerin verdiği birtakım bilgileri gereksiz görüp müdahale ederken, reddettiği şarihler için "1tnâb-1 kelâm ve iksâr-1 makâl eylemiş, ıtnâb-1 bî-faide eylemiş, mutnıb imiş" gibi ifadeler kullanır: 
Pes ma'lūm ola ki 'umūmen şurrāh bu beytüñ ma'nāsına vāṣıl olmamışlar. Ve ba'żısı şöyle ıțnāb-1 kelām ü makāl eylemiș ki méāl ü netīcesi maḩ̇̇-1 jāj belki andan dūn u sāfildür. Te'emmel ve tedebber (Redd-i İbn Seyyid 'Ali ve Lāmi'ī ve Redd-i Sürūrī ve Şem'ī ve Kāfī), (Şerh-i Gülistân, 22a)

Zülāl, țatlı șuya dirler. Pes zülāl vaṣfında iṭnāb eyleyen mutnib imiș (Redd-i Kāfī), (Şerh-i Gülistân, 84a).

Nān-1 ribāṭ lāmiyye. Bunda ribāṭdan murād huānḳāh ve tekye gibi yerlerdür. $\mathrm{Bu}$ maḳāmda ribāțuñ müşterek ma'nālarını żikr idüp tațvīl-i kelām eyleyen ıtnāb-1 bī-fā'ide eylemiş (Redd-i Sürūrī), (Şerh-i Gülistân, 114a).

Bu iki beyt eş'ār-1 'Arab üslūbı üzre vākị olmış. Pes bu țarz u țariḳayı bilmeyen bunı muhaḳḳaku'l-vukū' z̧ann idüp ı̣tnāb eyleyenlerüñ teks̄īr-i kelimātına i'tibār olunmasun (Redd-i Sürūrī ve Şem $\left.{ }^{(}\right)$), (Şerh-i Divan-ı Hafız, III, 304).

Şarihin belâgat unsurlarına dair bir diğer eleştirisi, maanî ve beyan ilimlerinin bir kolu olan edebî sanatların yanlış tespiti ve eksik söylenmesine dairdir. Buna göre diğer şarihlerin buldukları bazı edebî sanatların doğru ve yerinde olmadığını ifade ederek bu konuda kendi görüşünü ortaya koyar. Mesela aşağıdaki örnekte leff ü neşr, teşbîh, tarsî, tecnîs-i mutarraf, müsecca-ı mutarraf sanatlarının ismini zikretmiş, diğer şarihlerin teşbîh ve tarsî sanatlarıyla ilgili yorumlarını reddetmiştir:

Güftì ki hurde-i mīnā ber-hākeş rīhte ve 'ıkd-ı Sü̈reyyā ez-tārekeş der-āvīhte. Leff ü neşr-i müretteb țarīkıyla buyurur: Eger sen ol mevżi ve dırahtānı göreydüñ dirdiñ ki ol mevżi'üñ hāki üzre yeşil șırça uvag̉ı dökülmiş. Çemen, envā'-1 şükūfeyle mülemma' olduġını leme'ān u beraḳānda yeşil șırçaya teşbīh eylemiş. Ve ol dirahtānuñ depesinden Ülker dizisi ve bog̉umı aṣılmış ve șarḳmış. Elmanuñ ve emrūduñ ve kirāzuñ ve gayrınuñ tọp țop olan çiçegini '1ḳd-1 Süreyyāya teşbīh eylemiş. Ḩākeş żamīrini būstāna ircā' idüp beyān-1 ma'nāda evrāḳ-1 dırahtān zikr eylemek garīb tașarrufdur. Ve fiḳra-i șāniyede "dahı evvelüñ bog̉umı ya'nī 'ı̣̣da benzer Śüreyyā ol dırahtlaruñ farḳından aṣılmış" diyen teșbīhde iğrāb eylemiş (Redd-i Şem'ī ve Sürūrī). Fıḳra-i șāniyede "tārekeş bedeli tākeş idi, fiḳra-i ūlā ile șan'at-ı tarșī' olurdı" diyenler ma'lūmdur ki șan'at-1 tarșî̀ 
ne olduğını ve nice olduğını bilmezler imiş (Redd-i Şem'ī ve Kāfì). Belki hāk ü tāk beyninde tecnīs-i mutarraf ve rīhte vü āvīhte beyninde müsecca'-1 mutarraf olurdı (Şerh-i Gülistân, 23a).

Aşağıdaki örneklerin ilkinde Sürurî́nin "el-medh bimâ yüşbihü'zzemm sanatı var" dediği kısmın "muhtemilü'z-zıddeyn" sanatı olması gerektiğini söylerken, ikincisinde İ̉bn Seyyid Ali'nin mübâlağa şeklinde görüş bildirdiği yeri Sürurî́nin reddetmesini eleştirir:

Her ki der-sāye-i 'ināyet-i ūst / Güneheş țā'ātest ü düşmen dūst : Beytde muḥtemilü'ż-żıddeyn șan'atı var. "el-Medḥ bimā yüşbihü'z-zemm" diyen galaț söyledi (Redd-i Sürūrī), (Şerh-i Gülistân, 26').

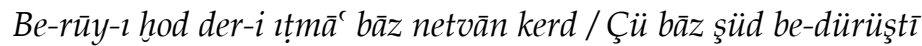
firāz netvān kerd: Netvān kerd 'ibāretinde İbn Seyyid 'Ali mübālag̉a var dimiş ve Sürūrī ma'nā-yı mübālag̉ayı inkār eylemiş lākin inkārı münkerdür (Redd-i Sürūrī), (Şerh-i Gülistân, $\left.50^{\mathrm{b}}\right)$.

Şerh-i Bostân'dan aldığımız aşağıdaki örnekte, beyitte geçen mübalağayı farketmeyen Sürurî ve Şem '̂̀'yi yanlış değerlendirmelerde bulundukları için reddeder:

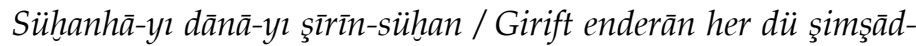
bün : ... Şimşād-bün, vașf-1 terkībīdür. Şimşād, şīnuñ fethii ve kesriyle ve sükūn-1 mīmle çimşir ag̉acı. Bün, bā-yı 'Arabuñ żammıla dib ve kök ma'nāsınadur. Ammā bunuñ gibi yirlerde ocaḳ dimekle ta bīr olunur mübālag̉a țarīḳıyla. Meșelā gül-bün gül ocaġı ve şimşād-bün çimşir ocaġı dimekdür. Pes ḳadd-ile ve fidān-1la beyān idenler mežkūr mübālag̉adan āgāḥ degüller imiş (Redd-i Sürūrī ve Şem'ī), (Şerh-i Bostân, 84º ).

\section{b. Şekil Bilgisine Dair Reddiyeler}

Şerhedilen metinlerden Gülistân, nazım-nesir karışık olarak yazılmış bir eserdir. Eser; nazım, rubaî, kıta ve mesnevî gibi nazım şekillerini barındırdığı için, şarihler metni hem şekil bilgisi hem de ölçü ve kafiye gibi yönlerden değerlendirmiştir. Sudî, bu değerlendirmeler sırasında Gülistân'ı şerheden diğer şarihlerin bazı tespitlerini yerinde bulmamış, 
sebeplerini söylemek suretiyle reddiyeler yazmıştır. Bu reddiyeler arasında rubaî, nazım ve kıta nazım şekillerinin birbirine karıştırılması sonucu ortaya çıkan hatalarla ilgili olanlar ilk sıradadır. Mesela aşağıdaki reddiyelerin ilkinde nazmın nesir olduğunu farkedemeyip, ilgili kısma kıta yerine hikmet başlığı veren Sürurî eleştirilirken, ikincisinde, kıta üslubuyla yazılmış bir manzume için "gazel üslubuyla yazılmış" diyen Şem'î ve Sürurî reddedilir:

Bu naẓmı neşr zann idüp ḳıṭ̣a yerine hịmet yazan nazmı neșrden farḳ eylemezmiş (Redd-i Sürūrī), (Şerh-i Gülistân, 236b).

Ma'lūm ola ki mežkūr üslūb ḳıț'a üslūbıdur, gazel üslūbı degüldür. İmdi bunı ġazel üslūbına ḳoyanlar ziyāde üslūbsuzlı̣ eylemişlerdür (Redd-i Sürūrī ve Şem̄ī), (Şerh-i Divan-ı Hafız, II, 252).

Şarihin şekil bilgisine dair reddiye örnekleri şöyledir:

Rubā'ì̄, dört mișra'dan mürekkeb naẓma dirler ki mațla's ola. Ve dördünci mıșrā'inuñ ḳāfiyesiyle müttefik ola. Ve baḥr-i hezec-i ahrebden ola. Pes buña muṭlaḳā naẓm ve kı̣ṭ́a diyenler vezn-i rubāî̄den āgāh degüller imiş (Redd-i İbn Seyyid 'Ali ve Lāmi'ī ve Kāfī), (Şerh-i Gülistân, 12a).

Bu iki beytüñ nazmina ḳṭta ve rubā'ì diyenler ne ḳıṭayı añlarmış ve ne rubā'īyi (Redd-i İbn Seyyid 'Ali ve Sürūrī), (Şerh-i Gülistân, 30).

Bunda ḳıṭ́a yerine naẓm ve şi'r yazanlar ḳaleminden sehv vāḳi' olmış (Redd-i İbn Seyyid 'Ali ve Lāmi'ī), (Şerh-i Gülistân, 31

Bu iki beyti rubā'î̀ deyü yazanlar ahvāl-i naẓmdan 'aceb bībehre imişler (Redd-i İbn Seyyid 'Ali ve Sürūrī). Ve bu naẓma beyt iṭlāk eyleyen ve şerhinde beyt yazan henūz beyt neye dirler bilmezmiş (Redd-i Şem īi), (Şerh-i Gülistân, 132b).

Bu iki beyti rubā'î̀ yazanlar aḳsām-1 şi'ri garīib eyi bilürlermiş (Redd-i Sürūrī ve Şem $\left.{ }^{(}\right)$), (Şerh-i Gülistân, 136'b). 
Bu iki beyti bir baḥrde zann idüp mesnevī yazanlar garīỉb bī-teşhīṣ imişler (Redd-i Sürūrī ve Seyyid 'Ali), (Şerh-i Gülistân, $\left.141^{a}\right)$.

Bu ḳıṭayı rubā'īler arasında yazup buña rubāè diyenler 'aceb bī-temyīz ü bī-teşhīṣ vücūdlar imiş (Redd-i Sürūrī ve Şem (̇i), (Şerh-i Divan-ı Hafız, III, 404).

\section{c. Vezne Dair Reddiyeler}

Klasik Türk şiirinde vezin, bir metni doğru okumak ve hakkıyla anlamlandırmak için gerekli hususların başında gelir. Aruz ilmi, üzerine çeşitli risaleler ve müstakil eserler kaleme alınacak kadar geniş muhtevalı ve hassas bir konudur. Şerhlerinde Aruz ilmine dair kaynaklar kullanan Sudî, aruzun yanlış uygulanması sonucu ortaya çıkan birtakım aksaklıkları ilgili terminolojiyi kullanmak suretiyle reddeder. Şarih, aruz veznine hâkim olmadan şerh yazmaya kalkışan diğer şarihleri eleştirir, olması gereken hususunda yorumda bulunmayı ihmal etmez:

Üftāde vāvla vāvsuz lügatdür. Vāvsuz yazup "vāvla da lügatdür" diyen ma'lūmdur ki nā-mevzūn oḳurmış (Redd-i Sürūrī), (Şerh-i Gülistân, 22b).

"Sīlīnüñ yāsına kesre hareket virilür żarūret-i vezn içün" diyenlerüñ șuratına sille urmak gerek aḥvāl-i vezne muțtalic degül iken böyle kitāblara şerh yazduḳları-y-çün (Redd-i İbn Seyyid 'Ali ve Sürūrī). Yãya kesre hareket virmeksüzin mevzūndur. Niteki hạżret-i Mevlānā Cāmī 'Arüżında besmeleyi taḳtī' eyledükde "mef'ūlü/mef'ūlü/fāilāt" buyurmışdur. Bunuñ da evveli "mef'ūlün" gelmekle nā-mevzūn olmaz. Nihāyeti sā'ir meșārīe takṭ̂̄íinde muvāfık olmaz līkin żarar virmez. Niteki evzānı tetebbu' idene ma'lūmdur. Nizāmīnüñ Mahzenü'lEsrārr evveli ve Nevāyīnüñ Hayretü'l-Ebrār $r$ evveli besmele ile vāḳi olmış. Ve sā'ir ebyātuñ taḳtịātına muvāfıḳ degül iken mevzūndur hażret-i Mevlānā Cāmīnüñ taḳțī eyledügi gibi (Şerh-i Gülistân, 132²).

“Ni'met tāsınuñ kesri işbā'la oḳunmak gerek ki nāmevzūn olmaya" diyenler nā-mevzūn imişler (Redd-i Şemī ve Sürūrī). Zīrā anı işbā'la oḳumaḳ beyti nā-mevzūn ider. "Hemçünān ki kāfını sākin oḳumaḳ gerek vezn içün" diyenler aṣlā 
evzāndan haberleri yoḳmış (Redd-i şurrāḥ cemīan), (Şerh-i Gülistân, 210).

Şeñ̄dem ki nāmeş Hudā-dūst būd / Melek-sīretī àdemīinūst būd: ... Ādemī ve ādem bir ma'nāyadur. Ya'nī ebu'l-beşer. Bu lafẓı yāsuz yazan nā-mevzūn yazup hațā eylemiş (Redd-i Şem'ī), (Şerh-i Bostân, 128a).

Ṭabīb yerine țabībān īrād eyleyen mevzūn ve nā-mevzūnı fark ider degül imiş (Redd-i Şem'ī), (Şerh-i Divan-ı Hafiz, III, 362).

\section{d. Kâfiyeye Dair Reddiyeler}

Klasik Türk şiirinde biçim ve ahengi oluşturan unsurlardan kafiye, tıpkı ölçü gibi başı başına bir ilim sahasıdır. Ele alınan metinler şiir olunca, şarihlerin de bu ilim sahasında bilgi sahibi olması kaçınılmazdır. Ancak kafiye tespit ve tayini bir hayli dikkat isteyen çetin bir iştir. Sudî, şerhlerinde kafiye hususundaki düşüncelerini bildirirken, diğer şarihlerin görüşlerini delil göstermek suretiyle reddeder. Kafiyeye dair reddiyelerinde işba, revm-i zamme, mamul gibi kafiye terimleri kullanır, kafiyeye dahil olan/olmayan harflerle ilgili tespitlerde bulunur:

Horden, vāv-1 resmīyledür; Fārisī, revm-i żamm-1la oḳınmak gerek. Elifle ve elifsüz lüğatdür. "Kāafiye eclinden bunda hā meftūh oḳınmak gerek" diyen revm-i żamme ma'nāsından gāfil imiş ki hāyı meftūḥ oḳımag̉ı kāfiye żarūretine tahșīṣ eyledi (Redd-i Şem $\left.{ }^{\mathrm{i}}\right)$, (Şerh-i Gülistân, $4^{\mathrm{b}}$ ).

$M \bar{a} z \bar{a}$ ehādake yā mağrūrü fi'l-hațari / Hattā helekte feleyte'nnemle lem yaṭıri: Ba'żi şāriḥ "lem yaṭıruñ țāsı meftūḥ oḳunmak gerek hațaruñ țāsına ḳāfiyede muvāfık ola" dimiş ve ba'żısı fethüũ cevāzına hü̈km eylemiş. Līkin ikisi bile sehv eylemiş. Zīrā tạa ve hareketi huurūf u harekāt-1 ḳāfiyede dāhil degüldür. Fe-tedebber (Redd-i İbn Seyyid 'Ali ve Sürūrī). Ve "lem yaṭırda țā fetḥle ve rā kesrle oḳunur ḳāfiye żarūreti içün" diyen hațā eylemiş. Zīrā țānuñ ḥāli mežkūr gibidür ammā rānuñ kesri ve tevellüd yāsı żarūret-i vezn içündür, żarūret-i ḳāfiyeye ta'alluḳı yoḳdur. Fe-te'emmel (Redd-i Şemī), (Şerh-i Gülistân, 132a). 
Çi yārī küned miğfer ü cevşenem / Çü yārī nekerd ahter-i revşenem: ... Ahter-i revşen beyāniyye. Rāyı ba'ż-1 'Acem meftūḥ ve ba'żısı mażmūm oḳur. Bunda ikisi de cā'izdür. Līkin fetḥ ensebdür. Niteki fenn-i ḳâfiyeden haber-dār olana ma'lūmdur. Pes żarūret-i ḳāfiye içün rā meftūḥ oḳunmaḳ gerekdür diyen fenn-i ḳāfiyeden bī-ḩaber imiş̧ (Redd-i Şem'ī), (Şerh-i Bostân, 429 b).

... Bu ḳıṭ̂anuñ üç beytinde şīn-1 żamīrüñ mā-ḳabli meksūr oḳınur żarūret-i ḳāfiye içün. Fenn-i ḳāfiyede bu üslūba ma'mūl dirler. Niçe nev' olur. Pes bu ḳāideyi bilmeyüp bir fi'l taḳdīr idenler fenn-i ḳāfiyeden 'ārī imiş (Redd-i Şem'̄̄), (Şerh-i Divan-ı Hafiz, III, 384).

\section{4. İmlâya Dair Reddiyeler}

Şerhedilen metinlerde geçen Arapça-Farsça kelimelerin doğru okunup doğru yazılması da şarihlerin dikkat etmesi gereken bir husustur. Sudî, Farsça ve Arapça kelimelerin yazılış ve okunuşu hususunda yap1lan birtakım yanlışları reddeder. Buna göre bir kelimenin yazımında gereksiz harf kullanımı (bilhassa hemze harfiyle ilgili), Farsça "est (-dır, dir)" yapısının doğru yazımı, Arapça kelimelerin okunuşunda teşdîd olup olmaması, bazı kelimelerin yazımında birbirine benzer harflerden (j- $j, b-ض, \tau^{-v b}$.) yanlış harfin tercih edilmesi gibi hususlarda diğer şarihleri reddeder:

Çün, edāt-1 teşbīh ve $\bar{\imath} n$, ism-i işāretdür ḳarībe. Ve sīn ve tā edāt-1 haber. Terkīb ile çünden vāv-ı resmī ve īnden hemze ḥaz̨f olup çünīnest old1. Buncılayındur dimekdür. Bu lafz̧ı çünīnest hemze-i müctelibe ile yazanlar Fārisī imlādan āgāh degüller imiş (Redd-i İbn Seyyid 'Ali ve Lāmi'ī ve Sürūrī ve Şem'ī ve Kāfī), (Şerh-i Gülistân, 19a).

"Kām bunda, kāf-1 'Acem-ile" diyenler hațā-yı fāḥiş eylemişler (Redd-i İbn Seyyid 'Ali ve Lāmi'ī ve Sürūrī ve Reddü'lHakāyık ve Kāfī), (Şerh-i Gülistân, 21ª).

Bațīst lafụını bațiest yazan imlādan āgāh degül imiş (Reddi İbn Seyyid 'Ali ve Lāmi'ī ve Sürūrī ve Şemīi ve Kāfī), (Şerh-i Gülistân, 28º). 
Mūca', ism-i mef'ūldür if'āl bābından ya'nī müfred-i müzekker-i gā’ib, mis̄āl-i vāvīden. Veca', vāvuñ ve cīmün fetḥalarıyla ag̉rnya dirler. Mūca'nuñ cīmini teşdīd ile ḳayd eyleyen vücūd-1 şerīf 'aceb vezn-i țab'a mālik imiş (Redd-i Sürūrī), (Şerh-i Gülistân, 177a).

Gūz, kāf-1 'Acemüñ żammı ve zā-yı 'Arabla bügri dimekdür. "Zā-yı 'Acemle" diyenler bu ebyātuñ kāfiyelerine nāẓır olmamışlar (Redd-i Halīmī ve Ni'metullāh), (Şerh-i Gülistân,189a).

Șan'ān, bilād-1 Yemenden bir 'azīm beldenüñ ismidür ki 'Abdü'r-rezzāḳ-1 Yemen̄̄ andandur. 'Arab hemze ile oḳur ammā 'Acem nūn-1la. Pes nūn-1la hațādur diyen ḩațā eylemiş (Redd-i Şem $\left.{ }^{(}\right)$), (Şerh-i Bostân, 410a).

Lafẓ-1 āzārı żāl ile yazanlar imlādan gaāfiller imiş (Redd-i Sürūrī ve Şem'ī) , (Şerh-i Divan-ı Hafiz, II, 188).

Tecemmül yirine cīmle taḥammül yazan hāa-y-la vaż'-1 noḳtada iḥmāl eylemiş (Redd-i Şem̄i), (Şerh-i Divan-ı Hafiz, II, 207).

\section{Sıhhatli Nüshaların Değerlendirilme(me)sine Dair Reddiyeler}

Edebî çevrelerde beğenilip takdir gören klasik metinler, çok okundukları için onlarca nüshaya sahiptir. Klasik eserler arasında yer alan Gülistân, Bostân ve Divan-ı Hafız, yüzyıllar boyu sürekli olarak çoğaltılmış, okunup yorumlanması gelenek haline gelmiş metinlerdir. Sürekli kopya edilen bu metinler, sık el değiştirmeleri sebebiyle bir süre sonra bazı nüsha farklılıkları göstermeye başlamıştır. Bu noktada şarihlere düşen, bu eserlerin farklı nüshalarını bir araya getirip nüsha farklarını değerlendirmek, ibarenin siyâk u sibâkına uygun kelimeyi metne yerleştirmek, böylece en doğru anlamı yakalamak için gerekli düzeni sağlamaktır. Tabii ki bu gayret, yoğun bir zihin mesaisini beraberinde geirir. Bu yoğunlaşma sonucunda metne ait "en sıhhatli nüsha"nın ortaya konulması amaçlanır. Sudî’nin şerhleri, nüsha tenkidi açısından oldukça zengindir. Sudî, diğer şarihlerin farklı nüsha tercihlerini çoğu zaman eleştirmiş, onların seçtiği kelimeleri, sebeplerini açıklayarak reddetmiş- 
tir. Bazen de, bir metnin sahih nüshalarında olmayan bir kelimeyi, sehven ya da acelecilikle dikkate alıp metne dahil edenleri eleştirmiştir:

Ma'lūm ola ki Gülistānuñ ḳadīm nüshalarında ki her geh ki yekī ez-bendegān vāḳī'dür ve ekșerinde geh yekĩ düşmiş ammā rābıțasuz yek̄̄ nedretle vāki dür. Pes ḳadīm nüsḩalara muhālif yazanlar ma'nā-yı müstakīme muhālif yazmışlar. Fe-tedebber (Redd-i İbn Seyyid 'Ali ve Lāmi'ī ve Sürūrī ve Şem'ī ve Kāfī), (Şerh-i Gülistân, 7b).

Ba'żı nüshalarda emān u selāmet vāv-1 'āṭfe ile vāḳi'dür 'aṭf-1 tefsīrī şekli... Ammā yerine libās żikr idenler iki yerde sehv eylemişler. Evvel bu ki emān u zamān tecnīs-i muțarrafdur. S̄āniyen iki fiḳrada zü̈'l-ḳāfiyeteyn vāḳi'dür. Te'emmel (Redd-i İbn Seyyid 'Ali ve Sürūrī ve Kāfī), (Şerh-i Gülistân, 15a).

Şeb-rā be-būstān-ı yekī ez-dūstān ittifāk mebìt üftād. Ma'lūm ola ki bu kitābuñ bu maḥalli eski nüsḩalarda böyle vāḳi'dür. Ve fi'l-vāḳi böyle gerek, tā kim aşag̉ada dīdemeş żamīrini ircāc eylemede tereddüd vāḳi' olmaya. Ya'nī mercū' yār-ı ḳadīm ola bilā-tereddüd. Pes 'umūmen şurrāḥ bu maḳāmdan gafletle geçmişler. Te'emmel. (Redd-i İbn Seyyid 'Ali ve Lāmi'î ve Sürūrī ve Şem'ī ve Kāfī), (Şerh-i Gülistân, 22b).

Ber-men-i ūftāde düşmen-kām / Āhir ey dūstān güzzer bikünīd: Düşmenüñ murādınca ben ūftādenüñ üzerine ya'nī düşmenüñ istedügi diledügi gibi bir düşmişüñ üzerine elbette ey dostlar güzerer eyleñ. Bu 'ibāret iki ma'nāya mütehammildür. Ya'nī beni 'yyāde eyleñ veyā ḳabrümi ziyāret eyleñ dimek ola. Ba'̇̇-1 nüsahda bu beytüñ mıșā̄-1 evvelini ber-men üftāde merg-i düşmen-kām yazmış ve Seyyid 'Ali bizüm yazdugumuz gibi yazmış. Līkin ma'nāsını taḥ̣̂ị idememiş. Ve sā'iri terkībinde hațā eyledükleri gibi ma'nāsinda da hațā eylemişler. 'Ale'l-ḩuṣūṣ Kāfī ol ḳadar yāveler söylemiş ki istimā'ı șudā' degül cünūn īrās ider (Redd-i şurrāḥ cemī'an), (Şerh-i Gülistân, 46ª).

Eblehī k'ū rūz-ı rūşen şem'-i kāfūrī nihed / Zūd bìñ̄ keş be-şeb rüğan nebāşed der-çerāg : Bir ebleh ki aydın günde ya'nī güpegündüz şem'-i kāfūrī yaḳar, yaḳın zamānda görürsin çerāġdānında yag̉ olmaz, ya'nī iç yag̉ı veyā bezr yağ1 yaḳmag̉a ḳādir olmaz, ḳanda ḳaldı ki zeyt yağı ve şırlag̉an yağı. Hāạılı 
böyle isrāf eyleyen aḥmak az zamānda şöyle müflis ü faḳīr ola ki eñ ucuz olan yağı yaḳmag̉a ḳādir olmaz dimekdür. Ba'ż-1 nüsahlarda nebāşed yerine nemāned gelmiş ve şurrāhuñ ba'żısı anı iḩtiyār eylemiş. Ve ba'żısı bu muhtāra dahl eylemiş ki terkībden eblehüñ rūgan yaḳduğı mefhūm degüldür ki çerāġında rūgàn ḳalmaya denile. Ve ba'żısı im‘ān-ı naz̧ar eylemeyüp muhtāra mu'āvin olmış ve hayli ikșār-1 kelām eylemiş līkin țarīḳ-1 mükābereye sülūk eylemiş (muhtār İbn Seyyid 'Ali

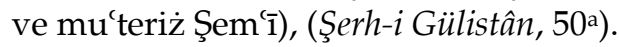

Be-dest āheg-i tafte kerden hamīr / Bih ez-dest ber-sinne pīş-i emīr : Mıșrā-'-1 șānīyi bih ez-dest ber-dest pīş-i emīr yazanlar nādir vāḳi olanı ihtiyār eylemiş (Redd-i Sürūrī ve Şem $(\overline{1})$. Ba'̇̇-1 nüsahda āhen-i tafte vāḳi olmış. Mübālag̉a țarīḳıyla ḳızmış dimür dimekdür. Dest ber-dest nüshasinı dest ber-sine nüshasina tercīh eyleyen nādiri meşhūra tercīḥ eylemiş (Redd-i Kāfī), (Şerh-i Gülistân, 80 $)$.

Peder güft: Ey püser! Menāfi-i sefer ber-īn nemaț ki güftī bisyārest velīkin penc țā'ife-rā müsellemest. Evvel bāzargāñ̄ ki bā-vïcūd-ı ni'met ü miknet ġulāmān u kenīzān-ı dil-āōiz ü şāgirdān-ı çāpük dāred. Her rūz be-şehrī ve her şeb be-makāmī ve her dem be-teferrüc-gāhī ez-na'ìm-i dünyā mütemetti' şeved. Ba'ż-1 nüsahda müsellem yerine sinn ve tā -ki edāt-1 haberdür, vāki olmış, penc țā'iferāst dimiş. Ba' $\dot{z}-1$ şurrāḥ böyle yazmış bi-'aynihī ve ba'żısı iftirā eylemiş ki be-pencüñ evveline bir bā-yı șıla īrād eylemiş diyü. Līkin pes ma'lūm oldı ki yanında vāki ' olan nüsha ya ziyāde saḳīm yā ta'așṣuban iftirā idermiş. Böyle i'tirāżı çoḳ vāḳi' olıyorur e'ūzuü billāhi min-şürūri enfüsinā ve min-seyyi'āti a'mālinā (Redd-i Sürūrī). Ba'żı nüsḩada evvel yerine nühustīn vāḳi'dür (Şerh-i Gülistân, 141ª).

Ba'ż-1 nüsahda lūriyān yerine düzdān düşmiş. Ve ba'ż-1 şurrāḥ bu nüsḩayı ittiḩāz eylemiş ve ba'żısı mütūnı 'adem-i tetebbu'dan aña i'tirāż eylemiş līkin i'tirāżı zā'iddür. Zīrā lūrī cinsi elbette düzd olur Rūmuñ çengānı gibi (Redd-i Sürūrī), (Şerh-i Gülistân, 148a).

Dīdem yirine bāşed yazan cemī` nüsḩalara muhālif yazmış (Redd-i Sürūrī), (Şerh-i Bostân, 78). 
Bihūşsîd: ... Bā-yı te'kīd yirine nūn-1 nāfiye ile nehūşīed yazan șaḥị̄ nüsḩalara muhālif yazmış (Redd-i Sürūrī), (Şerh-i Bostân, 135a).

Be-kām enderem:... Be-kām enderūn yazan șahịḥ nüsḩalara muhālif yazmış (Redd-i Sürūrī), (Şerh-i Bostân, 138a).

Ba'żı nüsḩalarda bāṭıl yerine bāṭın yazar. Bāṭını bāṭıldan farḳ eylemezler (Redd-i Sürūrī ve Şem̄ì), (Şerh-i Divan-ı Hafız, I, 348).

\section{Verilen Bilginin Yanlışlığına/Eksikliğine Dair Reddiyeler}

Sudî, diğer şarihlerin yanlış ya da eksik verdiği bilgileri de reddeder. Verilen bilginin yanlışlığını/eksikliğini tenkit ederken, bunu bağladığı birtakım nedenler vardır. Buna göre diğer şarihleri bu tip yanlışlara iten başlica sebepler bilgi yetersizliği ve metin üzerinde yeterince düşünmemektir. Aşağıdaki örnekte "hiçbir peygamberin irilik ile vasfedilmediğini" ileri süren şarihleri, "bütün peygamberleri görmek mümkün olmadığına göre bu bilgiyi neye dayanarak verdiniz?" diyerek sorgular:

"Enbiyādan hīç birisi cesāmet ile mevșūf degüldür" diyenler 'aceb bu ḳadar biñ enbiyānuñ cemīini bildiler mi ki bu hükme cezm eylediler (Redd-i şurrāh cemī'an). Hele țūl-i ḳāmeti ḥażret-i Âdeme isnād eylemek meşhūrdur ammā anı da Allāh bilür ve peyġamber ancak (Şerh-i Gülistân, $6^{\text {b) }}$.

Aşağıdaki örnekte ise "şeyyâd" kelimesinin Anadolu ve İran'da kullanılan bir kelime olduğunu iddia eden Sürurî́yi, manasını iyi bilmediği bir kelimeye yanlış mana vermekle suçlar:

Kıș̣̦a-ḩ’ānlara da şeyyād dirler. Pes, "bu bir lafẓdur ki Rūmda ve 'Acemde müsta'meldür" diyü mücmel ḳoyan zāhir budur ki ma'nāsını bilse mühmel ḳomazdı ve gayrıya dahl eylemezdi (Redd-i Sürūrī), (Şerh-i Gülistân, 78a).

Diğer şarihlerin bilgi eksikliğini gördüğü kısımlarda genellikle "bî-haber imişler, cemî'inin mechûlü imiş" gibi ifadelere yer verir:

Bā, bunda zā'iddür. Taḥsīn-i lafẓ içün gelmişdür diyenler mežkūr taḳīrden bī-ḩaber imişler (Redd-i Kāfī ve İbni Seyyid 'Ali ve Sürūrī ve Şem'ī), (Şerh-i Gülistân, 2a). 
Şurrāḥuñ hīç birisi murg̀-1 eyvāna ta'arruż eylemedüginden ma'lūmdur ki cemīinüñ mechūli imiş (Redd-i şurrāḥ cemī'an), (Şerh-i Gülistân, 102 ${ }^{\mathrm{b}}$ ).

Şehr-i Vāsıț, Baġdād ile Bașra beyninde bir şehirdür ki Bag̉dād cānibinden gelen siyāh kalem ol diyārda hāṣıl olur. Anuñ-çün ḳalem-i Vāsıținn dirler. Līkin şurrāḥ şehr-i Vāsıṭ̂ żikr eylememişler. Zāhir budur ki bu kitābı çoḳ görmemişler (Reddi şurrāḥ cemī'an), (Şerh-i Gülistân, 127a).

Metne hâkim olmadan, metnin ne dediğini anlamadan hareket edip aceleyle ve düşüncesizce (teemmül ve tefekkürsüz) yorum yapan şarihler, Sudî tarafından sürekli reddedilmiştir. Sudî böyle kısımlarda acelecilik, farkında değillik ve dalgınlık anlamlarına gönderme yapan "teemmülsüz fikr eylemiş, indî söylemiş, gâfil imiş, âgâh olmamışlar" gibi ifadeler kullanir. Mesela,

"Ki burada edātdur, mā-ḳablini mā-ba'dına irtibāṭ için gelmişdür" diyen ne rabṭ eyledügini ta'yīn eylememek ḳıllet-i te'emmülden nāşīdür. Redd-i Şem 'ī), (Şerh-i Gülistân, 2a).

örneğinde Şem'î́yi "ki" edatının görevini bilmemekle değil, düşünmeden aceleci yorum yaptığı için eleştirir. İbn Seyyid Ali'yi de,

Hā-yı resmīyle nūn-1 nāfiyeyi meksūr oḳımag̉a hükm ḳıllet-i te'emmülden gelür (Redd-i İbn Seyyid 'Ali). Belki meksūr oḳınan nūn-1 nāfiyedür, yāyla yazılur ve oḳınur. $N \bar{\imath}$ dirler meselā (Redd-i İbn Seyyid 'Alī), (Şerh-i Gülistân, $3^{\mathrm{b}}$ ).

diyerek reddederken sorunu yine metne yeterince hâkim olmamakta görür. Benzeri başka örnekler de vardır:

Ey kerīmī ki ez-hızāne-i ġayb / Gebr ü tersā vazîfe-hor dārī : Kerīm, münādā ve yā, harf-i vahdet. Ey bir kerīm dimek olur veyā münādā muḳadder ola, yeă, hițāb-1 hāliṣ ma'nāsına ola. Taḳdīri, "ey Hudā kerīmsin" dimek ola. "Bunda yā, hițāb içündür vaḥdeti müteżammı" ve "kerīmde olan yā hițāb-1 ferdiyyedür" diyenler 'indī söylemişler (Redd-i Lāmi'ī ve Şem 'ī). Zīrā Fārisīde didükleri gibi yā yoḳdur... (Şerh-i Gülistân, 4a).

Ve dirahtān-rā be-hil'at-i Neorūzī kabā-yı sebz-i varak der-berkerde. Rā bunda, ḥarf-i tahșīṣdür. Dırahtlaruñ dimekdür. "Eşcāra ve dırahta" diyenler rānuñ tahșīṣ içün olduġına āgāh olmamışlar (Redd-i Şem'ī ve Lāmi î̀), (Şerh-i Gülistân, 5a). 


\section{B. ÜSLUP}

Her edebî metinde olduğu gibi şerhlere de ruhunu veren şarihin üslubudur. Şerhin amacı ve muhtevası şarihe fazla imkân tanımaz, ancak bu sınırı aşan şarihler yok değildir. Sudî, bunu başaran şarihler arasındadır. Sudî'nin şerh üslubunun belirgin biçimde hissedildiği yerler hiç kuşku yok ki reddiyeleridir. Çünkü şarih, reddiyelerinde kelimelerle âdeta oynar, mizahî bir edayla şerhini akıcı bir hale getirir. Bazen hem güldürüp hem öğretirken, bazen de alaycı bir tavır takınır. Kimi zaman reddettiği şarihin bilgisizliğinden dem vurur, kimi zaman öğretici bir edaya bürünür. Reddiyelerinde diğer şarihler için kullandığ1 "indî söylemiş (basit ve kendince söylemiş), k1llet-i te'emmülden nâşîüur (iyi düşünmemekten ileri gelir), âgâh olmamış (uyanmamış), isâbet eylememişler, mânâ cânibine nâzır değillermiş (anlama bakmamışlar), hatâ-yı fâhiş eylemiş (açıç̧a hata yapmış), aceb söylemiş (garip söylemiş), garîb mülâhazaya mâlik imiş (dikkatlice bakmamış), hakk-1 edâyı edâ idememiş (edanın hakkını verememiş), zâid söylemiş (boşuna söylemiş)" gibi ifadeler Sudî́nin kendine özgü üslubunun örnekleridir:

Çengī yāsını ḥarf-i maṣdar țutanlar ma'nā cānibine nāẓır olmamışlar (Redd-i Şemīi ve Kāfī), (Şerh-i Gülistân, 15º).

"Nīst, ne est taḳdīrindedür" diyen iṣābet eylememiş (Reddi Lāmīì), (Şerh-i Gülistân, 16a).

“Nahl-bendī yā-yı maṣdarī ile vaṣf-1 terkībīdür, naḳıl bag̉layıcılıḳ. Ya'nī naḳıl bag̉layıcılıḳ bilürem ammā būstānda degül ki envā'-1 şükūfe cem' idüp nahıl bag̉layaydum". Ma'lūmdur ki bu şārih beytüñ makṣūdını bilmemiş. Ve bu taḳrīrden ma'lūmdur ki mıșrā'-1 șānīyi de bir garīb vech ile şerh etse gerek (Redd-i Sürūrī), (Şerh-i Gülistân, 30a)

Mıṣrā'-1 evvelüñ ma'nāsını "çünki saña bir kimsenüñ gażabı üzerine hışm gele" diyen hạḳk-ı edāyı idememiş (Redd-i Şem $\left.{ }^{(}\right)$, (Şerh-i Bostân, 75º).

Beytüñ feḥvāsında nā-ma'ḳūl taṣarruflar idüp tırzịk ma'nālara virene iltifāt olunmasun ki șudāe īrās ider (Redd-i Şem $(\overline{1})$, (Şerh-i Bostân, 225ํ). 
Bunda rūz devlet ma'nāsınadur diyen bī-devlet 'indī söylemiş (Redd-i Şemī), (Şerh-i Bostân, 247b).

Mıșrā-1 șānīnüñ ma'nāsını "gàāiüun hayrān göñli vațana olur" diyenler ḥaḳk-ı edāyı eylememişler (Redd-i Sürūrī ve Şem $\left.{ }^{(}\right)$), (Şerh-i Divan-ı Hafız, II, 81).

Mıṣrā'-1 șānīde hițāb Hudāyadur diyen hațā-yı fāhịiş eylemişdür ve bu yire dek böyle hațāyı șad hezār eylemişdür (Redd-i Sürūrī ve Şemīi), (Şerh-i Divan-ı Hafız, II, 147).

Vāv, ḥarf-i ḥāl. Harf-i zā'id diyen zā'id söylemiş (Redd-i Şem (̄) ), (Şerh-i Divan-ı Hafız, II, 194).

Şarih, kimi zaman muhatabının bilgisiz olduğunu iddia eder, kimi zaman da eleştirdiği şarih için "Farsça bilmez" gibi küçümseyici ifadeler kullanir:

Āvered, vāvuñ fethịle fi'l-i mużāri'dür āverīdenden, gene vāvuñ fethịile. Vāvuñ żammıla oḳıyanlar Fārisī bilmez imiş (Redd-i Seyyid 'Ali ve Sürūrī), (Şerh-i Gülistân, 3º).

Günehgār: Güneh, günāhdan muhaffef ve gār, kāf-1 'Acemīyle edāt-1 fā'ildür, -ci ma'nāsına. Sitemgār ve cefāgār gibi. Bu kāfları 'Arabī dutanlar țutḳun țab' imiş ki hīç dimāğlarında Fārisī lezzzeti yoḳ imiş (Redd-i İbn Seyyid 'Ali ve Sürūrī ve Kāfī), (Şerh-i Gülistân, 7b).

Kec, kāf-1 'Arabuñ fethii ve cīm-i 'Arab-ile egri dimekdür. Kej de dirler kāf-1 'Arabuñ fethii ve zā-yı 'Acemle. Pes, "Keç sehvle vāḳi dür, zīrā keç kirece dirler" diyenler iki vechle sehv eylemişler. Birisi keç-kej mürādif olduġını bilmedükleri birisi de kec kirecidür. Z̄̄rā kireç geçdür kāf-1 'Acemle, 'Arabla degül. Hāșlı bunlar bu mīkdār bıżāatle Gülistān gibi kitābuñ șerhine ikdām eylemek ziyāde cünūndur (Redd-i İbn Seyyid 'Ali ve Sürūrī), (Şerh-i Gülistân, 107a).

örneklerinde adı geçen şarihlerin Farsça bilgilerinin eksik ve yetersiz olduğunu iddia etmektedir.

Sudî́nin reddiye üslubundaki en dikkat çekici husus, muhatabını tahfif ve tahkir edici ifadeler kullanmasıdır. Öyle ki yanlışını yakaladığı bir şarihin eksikliğini söylemekle yetinmez, tabiri caizse muhatabını yerden 
yere vurur. Şarih, bu kısımlarda birtakım kalıplaşmış ifadeler kullanır. Bu ifadelerin bazıları "yanından söylemiş", "iftira eylemiş", "manayı iyi bağlamamış", "takşîr eylemiş (kabuğunu soymuş, öze inememiş)", "...eylemek cünûndan nâşîdir (... yapmak delilik sebebiyledir)", "habt-1 aşvâ eylemiş (ancak kör kocakarıyı susturmuş)" şeklindedir:

Kāğid-1 zerden murād mežkūrdur. Pes şurrāḥuñ habṭ-1 'aşvā eylediklerine i'tibār olunmasun (Redd-i İbni Seyyid 'Ali ve Lāmi'ī ve Sürūrī ve Şemī ve Kāfī), (Şerh-i Gülistân, 10).

$\mathrm{Bu}$ beytüñ taṣvīinde şurrāḥuñ garīb tașarrufları vardur kim 'uḳalā gülmege lāyıḳdur (Redd-i şurrāḥ cemī'an), (Şerh-i Gülistân, 154').

Kilīm, kāf-1 'Arabuñ ve lāmuñ kesresiyle ma'rūfdur. Kāf-1 'Acemle diyen yanından söylemiş (Redd-i Şem'ī), (Şerh-i Bostân, $10^{\mathrm{a})}$.

Bazen de sırf bilgisizliği vurgulayan kelimeler kullanır. Bu ifadeler arasında "alçak kaçmış, zebûnlar imiş, rûstâyiliktir (köylülük), acemilik eylemiş, izhâr-1 cehl eylemişler" gibi azımsanmayacak miktarda tahkir edici olanları vardır:

Bunda çün vāv-1 aṣliyye ile i'tibār idüp "keyfe" ma'nāsına olmasını tecvīz idenler zebūnlar imiş (Redd-i Lāmi'ī ve Şem'ī), (Şerh-i Gülistân, 17a).

Biber: Bā-yı evveli bunuñ (gibi) yerlerde zurefā-yı 'Acem meksūr ve rūstāyīler mażmūm oḳurlar. Pes żammeye tahṣịṣ rūstāyīlıḳdur (Redd-i İbn Seyyid 'Ali ve Sürūrī), (Şerh-i Gülistân, 24a).

Kerdgār fa"āl-i muṭlaḳ ma'nāsınadur ya'nī Huudā. "Kāflar 'Acemīdür" diyen 'acemīlik eylemiș (Redd-i Lāmi'̄i). Ve kesr-ile diyenler bilmemiş (Redd-i Şem '̄i), (Şerh-i Gülistân, 24º ).

Dūn, alçak ma'nāsınadur ya'nī yaramaz. Żıdd-ı farḳ diyen alçak kaçmıș (Redd-i Sürūrī), (Şerh-i Gülistân, 51º).

Güm şüdüñ ma'nāsı yitdi dimekdür. Azdı dimek degüldür. Pes ḍalle fi'liyle tefsīr idenler azmıșlar (Redd-i İbn Seyyid 'Ali ve Sürūrī), (Şerh-i Gülistân, 54 ${ }^{\mathrm{b}}$. 
Ṭa'ne'î hemzesinde hạarf-i vaḥdet țutanlar izhār-1 cehl eylemișler (Redd-i Sürūrī ve Şem'ī), (Şerh-i Bostân, 83b).

Sudî́nin mizahî üslubu, esasen bir ibare veya cümlede geçen kelimelere dayanarak yaptığı reddiyelerde ortaya çıkar. Diğer şarihlerin verdikleri yanlış anlamlarla alay ederek, onları kendi kullandıkları kelimelerden hareketle reddeder. Sudî'nin şerh üslubunu akıcı kılan, kendisini diğer şarihlerden ayıran en önemli noktalardan biri de bu tür kullanımlarıdır. Şarihin üç şerhinden seçtiğimiz örnekler şöyledir:

Ber-dāred lafẓında beri ḥarf-i isti lā ve dārı, dāştenden alup "yuḳarı țutmaḳ" ma'nāsını virenler ma'nā-yı lüğavīleri üstāddan eyüce dutmamışlar (Redd-i İbn Seyyid 'Ali ve Şemī), (Şerhi Gülistân, 7b).

Bunda, "pest bā-yı 'Acemledür; Türkīde alçak dimekdür" diyen alçak ḳaçmışdur (Redd-i İbn Seyyid 'Ali). "Best, bāy-1 'Arabla fi'l-i māżīiür, bag̉ladı dimekdür. Pāy lafẓıyla terkīb olmağın ma'nā-yı maṣdarī murāddur ya'nī ayaḳ bag̉lamak gelmişdür șoñra dīvār" diyen burayı eyice baġlamamış (Redd-i Kāfī), (Şerh-i Gülistân, 30a).

"Ber bunda, ḳațāa ma'nāsınadur" diyenüñ ḳaṭ̂ā sözini diñlemek cā'iz degül (Redd-i Şem'ī), (Şerh-i Gülistân, 33'b).

Kem, kāf-1 'Arabīnüñ fethiyle eksük ma'nāsınadur. "Kāf-1 'Acemüñ żammiyla" diyen ma'nāyı güm eylemişdür (Redd-i Sürūrī), (Şerh-i Gülistân, 42a).

Mıșrā'-1 șanīnüñ ma'nāsını "ḳaçan bahādıruñ ḳarnı aç olsa ḳaçmag̉a muḥkem țutar ya'nī ḳudreti olmasa cenge aṣlā țāḳat getürmeyüp firār ider" diyen ma'nā-yı ḥaḳị̣atden firār eylemiş (Redd-i Kāfī), (Şerh-i Gülistân, 52a).

Ba'ż-1 nüsahda āhen-i tafte vāḳi` olmış. Mübālag̉a țarīḳıyla kıımış dimür dimekdür... Tafteye ısıcak ma'nāsını viren ḳatı șovuḳ söylemiş (Redd-i Sürūrī), (Şerh-i Gülistân, 80').

Mī nümāyed ve mī rübāyed fi'llerinden șoñra ḳulūb-ı evliyāyı zikr iden ma'lūmdur ki maḳṣūda vāṣıl olmamış (Redd-i Sürūrī). Ve mežkūr olan filler müfred olmak gerek. Cem ṣịgasıyla īrād eyleyenler ma'nālarıyla cem` olmamışlar (Redd-i 
şurrāḥ cemī'an). Mánālarını "bir dem gösterür ve bir dem ḳaparlar" diyen ve "virürler ve alurlar" diyen mülāḥaẓasuz virmişler ve almışlar (Redd-i Şem'ī ve Kāfī), (Şerh-i Gülistân, $\left.92^{\mathrm{b}}\right)$.

Gül ve sünbül mežkūr evșāfla oldugì gibi, berd-i 'acūzuñ bīminden el-ān süt içmemiş ț̣fl-ı dāyedür. Ya'nī reng ü būyları kemālde oldug̉ı gibi țarāvet ü tāzelikleri de kemāl mertebe idi. Beytüñ netīcesinde "ya'nī anuñ gül ü sünbüli berd-i 'acūzuñ havfından ve şiddetinden tamām açılmamış idi ammā açılsa Şeyh vaṣf eyledügi gibi olurdı" diyen beytüñ ma'nāsını açamamış (Redd-i Şem īi), (Şerh-i Gülistân, 112a).

Huandānı hạāl țutanlar bī-hāa imişler (Redd-i İbn Seyyid 'Ali ve Sürūrī). Ve "rev, reftenden müştaḳdur" diyen eyi varamamış (Redd-i Şem̄î). Mıṣrā'-1 şanīnüñ ma'nāsını "alnı açılmış olan kimsenüñ işi aşag̉a bağlanmaz" diyen ḳatı aşaġadan söylemiş (Redd-i Şem ${ }^{\mathrm{i}}$ ), (Şerh-i Gülistân, 128 ${ }^{\mathrm{b}}$ ).

Ṭāvūs yelegini muṣhaflaruñ evrāḳı arasında gördüm. Niteki 'ādeten og̉lancuḳlar țāvūs yelegini muṣhaflaruñ evrāḳı arasına ḳoyaġanlardur. Pes "muṣhaflaruñ varaḳları üzre țāvūs ḳanadını gördüm" diyen eyi görmemiş (Redd-i Şem̄i), (Şerh-i Gülistân, 142b).

"Lā-cerem bunda, sebeb ma'nāsınadur" diyen 'aceb böyle dimenüñ sebebi nedür (Redd-i Şem̄ī), (Şerh-i Gülistân, 150).

Veh, vāvuñ fethii ve hā-yı aṣliyye ile vāhdan muhaffefdür ki istigrāa ve teḥassür ve teḥazzün ve nedāmet maḳāmında müsta 'mel lafẓdur. Bun 'Arabī ẓann idüp esmā'-i ef'ālden olan vāhādan muhaffefdür añlayup -ki maḳām-1 ta'accübde müsta'mel lafẓdur- ve taḥkịkinini Muhtār-ı Șı ḩăha ihāale eyleyen kimsenüñ haḳḳında "vāh vāh" dimelidür (Redd-i İbn Seyyid 'Ali), (Şerh-i Gülistân, 199b).

Bered ber-dil ez-ceor-i gam bārhā/Ki nā-āzmūde küned kārhā: ... Mıșrā'-1 evvelüñ ma'nāsını "üzre gam elinden yüklü olur" diyen beytüñ ma'nāsını yaramaz yükletmiş (Redd-i Sürūrī), (Şerhi Bostân, 81a). 
"Firāz bunda, yaḳın ma'nāsınadur" diyen ıraḳ gitmiş (Redd-i Şem'ī), (Şerh-i Bostân, 409a).

Sirişkem der-țaleb dürhā çekānīd / Velī ez-vaṣl-ı ū bī-hāạṣlì būd: ... Mıșrā'-1 sānīnüñ ma'nāsında "anuñ vaṣlında bī-hāṣı̣llıḳ oldı" diyü yā-yı maṣdariyye i'tibār eyleyen bī-ḥāṣıl ḳāfiyeden bī-ḥāṣıl imiş (Redd-i Şem 'ī), (Şerh-i Divan-ı Hafiz, I, 398-399).

Müş̧ākem ez-berāy-ı Hudā yek şeker be-ḩand: ... Müştāḳum Allāh içün bir țatlu hande eyle ki mütelezzżiz olayım... Mișrā'-1 șānīnüñ ma'nāsını "müştāḳum Allāh içün bir būse hande" diyen gülecek ma'nā virmiş (Redd-i Şem '̄i)), (Şerh-i Divan-ı Hafız, II, 214).

Bes ki ez-eşk-i menet pāy fürū reft be-gil: ... Mișrā'-1 evvelüñ ma'nāsını "niçe benüm gözüm yaşından ayaḳ balçığa batdı" diyen ma'nā-yı beyti balçı̇a baturmış (Redd-i Sürūrī), (Şerh-i Divan-ı Hafiz, II, 224).

Der-zevāyā-yı țarabhāne-i Cemşīd-i felek / Erg்anūn sāz küned Zühre be-āheng-i semā' . Felek Cemşīdinüñ țarabhānesi bucaklarında Zühre yıldızı erġanūn çalup düzen virür semā' āhengiyle... Mıṣrā'-1 șānīnüñ ma'nāsını erg̉anūn sāz ide Zühre semā' āheng-ile diyen zühre semā' ḳașdına erganūn düze diyen beytüñ ma'nāsına düzen virmemişler. (Redd-i Sürūrī ve Şem'î̀), (Şerh-i Divan-ı Hafız, II, 384-385).

Menāmı ism-i mekān i'tibār eyleyenler gaflet uyḳusında

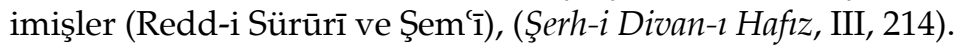

Sudî, bu üç şerhinde, metinleri Osmanlı Türkçesine çevirmekle kalmamış, diğer şarihlerin eksik ve yanlışlarını da belirtmek suretiyle Türk Şerh Edebiyatı'nda reddiye geleneğinin en önemli temsilcisi olmuştur. Reddiyelerindeki başarılı tespitleriyle, sadece kendi döneminde değil, ileriki yüzyıllarda da adından söz ettirmiş, kendine has bir tarz oluşturmuştur. Sudî́nin reddiyeleri, şarihlerin klasik bir eser üzerindeki yorumlarının her zaman doğru olmadığını, ne kadar donanımlı olursa olsun her şarihin hata yapabileceğini, bu yüzden şerh metinlerindeki yorumlara ihtiyatla yaklaşmak gerektiğini gösterir. Bundan hareketle, Gülistân, Bostân ve Divan-ı Hafız'ın tercüme ve şerhleri üzerine yapılacak çalışmalarda Sudî'nin görüş ve reddiyelerine başvurmak önemli katkılar 
sağlayacaktır. Çünkü Sudî, yaptığı yorumların pek azında yanlış hükümde bulunmuş, şerh geleneği içerisinde adından övgü ve takdirle söz ettirmiştir.

Türk Şerh Edebiyatı'nda reddiye geleneği, örneklerden de anlaşılacağı üzere, son derece canlı bir edebî tartışma ortamının metinlere yansımasıdır. Gerek sözlü olarak edebî çevrelerde, gerekse birbirini takiben yazılmış şerh metinlerinde örneklerine rastlanan bu gelenek göstermektedir ki, "metne hâkimiyet/mükemmel şerh" amacındaki şarihlerce yürütülen "şerh" faaliyetleri basit bir tercüme/çeviri işi değildir. Sıhhatli bir şerh için, farklı konularda ciltler dolusu kitap karıştıran, çalışma masalarında lügat, dilbilgisi, tarih, coğrafya, tıp, astronomi, belagat gibi ilimlere ait onlarca eser bulunduran şarihler, bu zorlu mesai sırasında ister istemez hataya düşmüş, tabiri caizse bir "sürç-i kalem" yaşamıştır. $\mathrm{Bu}$ yanılgıların, yine şarih kimliği taşıyan isimlerce takip edilip ortaya konması, esaslı bir edebî tenkit geleneğinin filizlenip baş göstermesini sağlamıştır. Şerh gibi zorlu bir işe girişen, şerh metinlerinde bilgi ve hüner gösterisi sunan şarihler, geleneğin bir getirisi olarak "reddeden bir kalem"in varlığını da hep hissetmiştir. Böylece şerh geleneği, kendi içinde çıkan hataları yine bir başka gelenekle kontrol altına almıştır. Sudî örneğinden hareketle bir fikir vermeye çalıştı̆̆ımız reddiye geleneği, Osmanlı kültürel birikiminin hangi seviyeye ulaştığını göstermede önemli bir ölçüttür. Şerhleri sadece Arapça-Farsça metinlerin tercümesi olmaktan çıkarıp ilmî bir zemine taşıyan bu gelenek, farklı örneklerin tespit edilmesiyle daha kapsamlı bir boyut kazanacaktır.

\section{Kaynakça}

Adanalı, A. Hadi (2001), "Osmanlı Medreselerinde Tartışma Metodolojisi", Osmanlı Dünyasında Bilim ve Ĕ̆itim Miletler Arası Kongresi: Tebliğler (12-15 Nisan 1999), IRCICA, 35-44.

Akpınar, Cemil (2002), "Kefevî Hüseyin Efendi", DİA, 25, 186-188.

Batuk, Cengiz (2007), “Reddiye/Polemik Geleneği ve Mevlânâ'nın Hıristiyanlık Algisı", Tasavouf, 20, 39-68.

Bursalı Mehmed Tahir (2000), Osmanlı Müellifleri (haz. Cemal Kurnaz-Mustafa Tatcı), Ankara: Bizim Büro Yay. 
Ceylan, Ömür (2000), Tasavoufî Şiir Şerhleri, İstanbul: Kitabevi Yay.

—, (2010), "Şerh (Türk Edebiyatı)", DİA, 38, 565-568.

Coşkun, Menderes (2007), Klasik Türk Şiirinde Edebî Tenkit (Şairin Şaire Bakışı), Ankara: Akçağ Yay.

Çaldak, Süleyman (2005), “Urfî-Dânlar Arasında Urfî̀nin Bir Beytinde Geçen "Abes" Kelimesi Üzerine Tartışmalar", Fırat Üniversitesi Sosyal Bilimler Dergisi, 15/1, 71-84.

Hoca, Nazif M. (1980), Sûdî, Hayatı, Eserleri ve İki Risâlesinin Metni, İstanbul: İÜEFY.

İsmail Hakkı Bursevî (2004), Rûhü'l-Mesnevî (Mesnevî Şerhi) (haz. İsmail Güleç), İstanbul: İnsan Yay.

Kara, İsmail (2011), İlim Bilmez Tarih Hatırlamaz: Şerh ve Haşiye Meselesine Dair Birkaç Not, İstanbul: Dergâh Yay.

Kara, Mustafa (1992), "Bâli Efendi, Sofyalı", DİA, 5, 20-21.

Karavelioğlu, Murat Ali (2005), On Altıncı Yüzyıl Şairlerinden Prizrenli Şem'înnin Divani'nın Edisyon Kritiği ve İncelenmesi, II cilt, DR, Marmara Üniversitesi Türkiyat Araştırmaları Enstitüsü, $659 \mathrm{~s}$.

Kartal, Ahmet (2001a), "Sa'dî-i Şîrâzî'nin Gülistân İsimli Eserinin Türkçe Tercümeleri", Bilig, 16, 99-125.

, (2001b), "Sa'dî-i Şîrâzî'nin Bostân İsimli Eserinin Türkçe Tercüme ve Şerhleri", Türk Kültürü İncelemeleri Dergisi, 5, 99-120.

Kâtib Çelebi (1971), Keşfü'z-Zunûn 'an-Esâmi'l-Kütüb ve'l-Fünûn, 2 cilt, İstanbul: MEB Basımevi.

Kefevî Hüseyin Efendi, Bostân-efrûz-ı Cinân Der-Şerh-i Gülistân, Süleymaniye Kütüphanesi, Hamidiye 1159, 206 vr.

Kılıç, Mahmut Erol (1996), "Fusûsu'l-Hikem”, DİA, 13, 230-237.

Kınalızade Hasan Çelebi (1989), Tezkiretü'ş-Şu'arâ (haz. İbrahim Kutluk-İbrahim Olgun), 2 cilt, Ankara: TTK Yay.

Murtaza Trabzonî, Şerh-i Kasâid-i Urfî, Süleymaniye Kütüphanesi Reşid Efendi 812, 1'b-133a.

Neşâtî, Şerh-i Ba'z-ı Müşkilât-ı Urfî, Süleymaniye Kütüphanesi Reşid Efendi $812,198^{\mathrm{b}}-229^{\mathrm{b}}$.

Öz, Yusuf (2010), Tarih Boyunca Farsça-Türkçe Sözlükler, Ankara: TDK Yay. 
Safvet, Şerh-i Cedîd-i Dîbâce-i Gülistân, Süleymaniye Kütüphanesi, Serez 2559,98 vr.

Sinanoğlu, Mustafa (2007), "Reddiye", DİA, 34, 516-521.

Sudî-i Bosnevî, Şerh-i Bostân, Bayezid Devlet Kütüphanesi Bayezid: 5494, 577 vr.

, Şerh-i Divan-ı Hafız, Süleymaniye Kütüphanesi Reşid Efendi 14251426-1427, 411+455+464 s.

, Şerh-i Gülistân, Bayezid Devlet Kütüphanesi Veliyüddin Efendi: 2693, 248 vr.

Sungur, Necati (2001), “Divan Şairlerinin Birbirlerine Yönelik Tenkitlerinin İlk Örneklerinden Biri: Cafer Çelebi'nin Şeyhî ve Ahmed Paşa'yı Tenkidi", Bilig, 17, 71-77.

Tâhirü'l-Mevlevî (1994), Edebiyat Lügati, İstanbul: Enderun Kitabevi.

Tolasa, Harun (2002), Seĥ̂, Latîfî ve Âşık Çelebi Tezkirelerine Göre 16. Yüzyılda Edebiyat Araştırma ve Eleştirisi, Ankara: Akçă̆ Yay.

Tuman, Mehmet Nâil (2001), Tuhfe-i Nâ'ilî (haz. Cemal Kurnaz-Mustafa Tatçı), Ankara: Bizim Büro Yay.

Ünver, İsmail (1985), "Şem'î Şem'ullâh", Türk Dili, 397, 38-43.

Yılmaz, Ozan (2004), "Urfî́nin Kasidelerine Yapılan Türkçe Şerhler", YL, Gaziantep Üniversitesi Sosyal Bilimler Enstitüsü, Gaziantep, 476 s. (2007), "Klasik Şerh Edebiyatı Literatürü", TALİD: Türkiye Araştırmaları Literatür Dergisi, 5, 9, 271-304.

—, (2010), “Şiraz'dan Trabzon'a Bir Kültür Köprüsü: Murtaza Trabzonî ve Urfî Şerhleri", Türk Dünyası Araştırmaları, 187, 139-158. , (2012), Gülistân Şerhi Sudî-i Bosnevî, İstanbul: Çamlıca Yay. 